\title{
THE GLASGOW (SCOTLAND) GEOTECHNICAL GIS: A DESK STUDY TOOL
}

David C Entwisle* ${ }^{1}$, Martin G Culshaw ${ }^{2}$, Andrew G Hulbert ${ }^{1}$, Wayne A Shelley ${ }^{1}$, Suzanne J Self $^{1} \&$ Marcus R Dobbs ${ }^{1}$

1 British Geological Survey, Keyworth, Nottingham, NG12 5GG, UK

2 British Geological Survey, Keyworth, Nottingham, NG12 5GG, UK and School of Civil Engineering, University of Birmingham, Edgbaston, Birmingham, B15 2TT, UK *Corresponding author (e-mail: dce@bgs.ac.uk)

\begin{abstract}
Desk study is an essential part of all civil engineering project site investigations. It is usually a collation and review of existing data and information about a site and is carried out at an early stage of site appraisal to inform and guide the site investigation. It should provide suitable information to assess the ground conditions and the implications for the proposed engineering design. A similar approach can be taken to inform local, regional or national government with regard to the redevelopment of urban areas where site investigation data are available. This paper describes a spatially defined geotechnical information system designed to provide geological and geotechnical data and information for Glasgow City Council (Scotland). The system contains three main parts, the geology (bedrock, Quaternary and artificial deposits and the thickness and depth of these deposits), a geotechnical and geoenvironmental database, and tools specifically developed to present the data. As undermining is a hazard in part of Glasgow, a dataset showing the distribution of mining is included. Further interpretation of the characteristics of the geological units has produced an engineering geological classification and this may be used to provide rapid assessment of the engineering geological conditions. [end of abstract]
\end{abstract}

\section{THE DESK STUDY}

Understanding the engineering geological and geotechnical variation of the ground for landuse planning or construction requires data and information. These are normally obtained through site investigation; this has a number of key stages (BSI 2007a) including the desk study. Information is gathered at the desk study stage of the site investigation following, perhaps, an earlier appraisal to identify specific risks. For local government, most site investigation reports are held in paper form or, more recently, as digital versions of the reports as 'pdf' files, which can be much more efficiently stored. However, there has been 
increased use of the digital data transfer format developed by the Association of Geotechnical and Geoenvironmental Specialists (AGS), as a method of reporting ground investigation data (AGS 2011). This provides an opportunity to greatly increase the use of these data, if they can be made available, as part of the land-use planning process and the desk study, whether by the consultants, local authority or their advisors.

As part of the engineering geological and geotechnical assessment it is essential to develop a ground model (Parry et al., in press). Over the last few years the British Geological Survey (BGS) has developed methods to produce 3D geological models (a type of conceptual model in the nomenclature of Parry et al.). These models, at a range of scales, provide a tool for 3D representation of the geology (in the broadest sense) that can be used, for example, for detailed site specific assessment of geology, lithology and structure for major construction works (Aldiss et al. 2012), in hydrogeological, contaminant transport and sustainable urban drainage infiltration assessments (Culshaw 2005, Kessler et al. 2008, 2009). An example of a 3D geological model classified for engineering geological purposes is shown in Fig. 1 for part of a central Glasgow (Ordnance Survey Quarter Sheet NS66SW). This model shows an engineering geological classification of the superficial deposits based on lithology (fine, coarse or variable) and consistency or density of each modelled geological unit. This type of model can inform land-use planning decisions. However, other than in the descriptive key, it is difficult for the model to show lithological variation within the modelled geological unit; this may be a particular problem for highly variable units such as anthropogenic deposits, which are present in many urban areas (Price et al. 2010). Making the data available as summary graphs, or providing the data, themselves, for further analysis, greatly increases the opportunities for using the information for desk studies. The advantage in developing such a system over an area for, say, a local authority is that it is likely to be used for many projects. This paper describes the geotechnical Geographical Information System (GIS) for part of Glasgow in Scotland, UK (the Glasgow Geotechnical GIS) (Fig. 2). The GIS was developed for a 10 x $10 \mathrm{~km}$ square study area covered by four Ordnance Survey topographical Quarter Sheets (NS56SE, NS56NE, NS66SW and NS66NW), which include most of central and eastern Glasgow. The GIS provides a better understanding of the complex bedrock and superficial geology to inform land-use planning decisions to be made by Glasgow City Council. The development of the GIS was based, in part, on an initial investigation of the engineering geology and geotechnical properties of a 5 x $5 \mathrm{~km}$ area (NS66SW) (Entwisle et al. 2008). 


\section{GLASGOW}

The Glasgow conurbation is Scotland's largest urban area (Fig. 2). It is built along the lower floodplain and inner estuary of the River Clyde and is flanked by hills. An important port from the $16^{\text {th }}$ century it became a trading centre from this time. With the increase in trade in the later $18^{\text {th }}$ century, coal and iron ore mining began in the area. During the $19^{\text {th }}$ century, the mining of local coal and iron ore expanded in response to the increase in associated heavy industries. This area became one of Europe's leading centres of heavy industry, based on metal working and ship building.

Geology of Glasgow

The geology of the area is complex, comprising faulted Upper Carboniferous bedrock (including extensive and shallow Coal Measures), Quaternary superficial deposits and artificial ground (Forsyth et al. 1996, Hall et al. 1998). The bedrock geology is summarized in Table 1 and the superficial deposits in Table 2. A series of 1:10 560 scale geological maps were produced between 1982 and 1984 as part of an environmental geological study of the Glasgow and Airdrie areas (Browne et al. 1986). Up to 12 different maps were produced for each quarter sheet. Many of these maps have a mining theme, which include shallow and deeper mines that are common in some parts of Glasgow. The complexity of the superficial deposits, identified during the environmental geology project, was further explored in 1989 (Browne \& McMillan 1989a, b). This research produced a series of outputs including maps of the surface distribution of Quaternary (superficial) deposits and profiles of the Quaternary deposits for the Dumbarton, Glasgow and Motherwell areas.

A 3D geological model of Glasgow was developed, in part, for the City Council to aid planning decisions. It includes artificial deposits, the superficial units identified in the previous work and the bedrock with the major faults (Campbell et al. 2010, Arkley et al. 2013).

\section{THE GIS}

The nature of the data used

The data used for the geological modelling and the GIS were primarily from BGS geological maps and site investigation reports provided to the BGS by project clients, consultants and contractors.. 
The preferred site investigation data used in the GIS, and the reasons for their selection, are listed below:

1. Data available in AGS digital data transfer format. These data are usually from larger site investigations for more 'knowledgeable' clients. These data have been added directly into the BGS National Geotechnical Properties Database (NGPD) (Self et al. 2012).

2. Reports for large site investigations post-1983. The new British Standard Code of Practice for Site Investigation, BS5930, was first published in 1981 (BSI 1981) and is likely to have been used for site investigations reported from 1983 onwards. Also, the first British Standard for laboratory testing of soils, BS1377, was published in 1975 (BSI 1975) (and revised in 1990 [BSI 1990]). Larger reports, particularly for roads, not only contain more data than smaller ones but often contain a greater range of insitu and laboratory test data.

3. Reports from smaller site investigations, post-1983, and larger pre-1983 site investigations were used to fill-in gaps in the data from the two types of reports described above.

Table 3 shows the types and proportions of geotechnical data available in pre-1983, 19832000 and post-2000 site investigation reports and their geographical distribution is shown in Fig. 3.

In the central Glasgow area some investigations included a large number of light cable percussion and rotary drilled boreholes. The former drilling method was used mainly in anthropogenic and superficial deposits and rotary drilling in bedrock. Many deeper boreholes were also drilled due to concerns about undermining.

The distribution of the site investigations included in the GIS depends on when and where development occurs. For example, in Glasgow many high-rise buildings were constructed during the 1960s and early 1970s to alleviate the housing shortagebut the site investigations for these developments are not included within the GIS. The poor occupant-experience of these buildings meant that construction of high-rise building stopped until the late 1980s. Similarly, the increase in car numbers and the need to expand the transport infrastructure led to the publication of the 'Highway Plan for Glasgow' in 1965. Although some of the motorways were constructed during the 1980s, the site investigations were carried out in the 1970s. More recently, site investigations for the Clyde Gateway, development area, 
completion of the M74 motorway and the facilities for the 2014 Commonwealth Games have all provided data including much in AGS digital data transfer format. A list of the major site investigations with more than 50 boreholes and pits and with dates of the project reports are given in Table 4. Many other smaller site investigations have been included in the GIS. As the site investigation data available from major road schemes were limited to the south and east of the project area and did not include all the lithostratigraphical units found within the project area, other data were included from smaller site investigations, such as those for housing estates. The complex lithostratigraphy and the local occurrence of some lithostratigraphic units at depths greater than the typical site investigation borehole meant that the geotechnical properties of a few units are not represented in the GIS, although their modelled extent is included.

\section{Databasing}

Geological, geotechnical and some geochemical data were added from site investigation reports into the NGPD. This is a relational database (for example, Connelly \& Begg 2005) with tables based on the AGS's digital data transfer format version 3.1 to which the lithostratigraphical unit, lithological and other codes are added. The basic structure of the database is shown in Fig. 4. The database dictionaries provide constraints on the inputs, generally codes, and describe their meaning, for example the codes and description for the lithostratigraphical unit. A number of queries are used to extract the data from the various database tables as required (Self et al. 2012).

The AGS digital data transfer format data were added to the NGPD. The data files were checked for any major errors using software developed by the BGS, for example, where the rules of the transfer format were not followed; examples include unrecognisable database field names and text in the data fields. These data were then corrected. Once the file has been accepted, a SQL (structured query language) script is created. This script is a series of commands that inserts the data values from the digital data transfer files into the appropriate tables on an AGS schema in the database. At this point, any errors in the data that break the rules of the database tables, such as text in numerical fields, are identified and corrected. The data are then mapped from the AGS schema into the NGPD in the BGS schema. The rest of the data were added manually from digital scanned copies (pdf) of the reports; all BGS site investigation holdings from Scotland and northern England (Cumbria, Durham and Northumberland) are scanned and stored as digital copies (pdf's). This was a great advantage as the records are available via personal computers to all BGS staff no matter where they are 
based. The entry of data from digital copies of site investigation report was time consuming and, inevitably, some data have been entered erroneously despite manual checking and these are corrected during analysis.

\section{Geological information}

Information on the geology of the central Glasgow area came from BGS digital geological maps in DigMap10 and DigMap50 at 1:10 000 and 1:50 000 scale, respectively. The maps included data on the bedrock, superficial deposits, artificial (anthropogenic) deposits and geological structure, particularly faults. The modelled units from the Central Glasgow Superficial Deposits Model (part of the overall geological model) were converted to ESRI (ArcGIS) and ASCII grids for addition and GIS requiring the data (Campbell et al., 2010, Arkley et al. 2013). This GIS includes separate data sets on:

- Anthropogenic and superficial units (shape files, .shp);

- Anthropogenic and superficial unit thickness (ASCII grid files);

- Anthropogenic and superficial unit tops and bases to mOD (height in metres relative to Ordnance Datum - the vertical datum used in the UK to derive altitude on maps in the UK) (grid files);

- Anthropogenic and superficial unit tops and bases depth below ground level (grid files);

- $\quad$ Selected bedrock units surfaces to mOD (grid files).

The shape files (polygons) show the extent of each modelled unit, which, in the GIS, are kept in stratigraphical order and the grid files, which have a resolution of $25 \mathrm{~m}$, show thicknesses or depths from a datum, in this case from Ordnance Datum or from the ground surface.

The artificial (anthropogenic) and superficial units were also classified in engineering geological terms (Table 5) as shown in Fig. 1, using methods developed for a series of research projects on the geological background for planning and development of a number of British cities and urban during the 1980s and 1990s (reviewed by Smith \& Ellison [1999]). The primary classification was by lithology, that is: fine-grained, coarse-grained and mixed lithologies. Further differentiation was in terms of consistency or density.

\section{Mining information}


One of the main geohazards in the Glasgow area is associated with past undermining. As part of an environmental mapping programme during the 1980s information on mining of all types in the area was compiled from mine plans (Browne et al. 1986). The principal mineral types were coal, sandstone, ironstone and fireclay. The number of seams worked was recorded and areas where one or more seams had been worked within $30 \mathrm{~m}$ of geological rockhead were considered to be of greatest subsidence hazard. These areas are presented in the GIS together with point information on adits and boreholes identified during this research that intercepted mined zones.

\section{Data confidentiality}

The main restriction on the provision of geotechnical and geoenvironmental data held by the BGS to industry is confidentiality. The site investigation data belong to the client. Some clients may have a long-term interest in the data, whilst others have little or no interest once the original project has been completed. Currently, the BGS considers most externally provided geotechnical and geoenvironmental data to be confidential and not available to third parties. This restriction means that site investigation data have been represented in reports as summary information, for instance in engineering geology reports for specific lithostratigraphical units (for example, Forster et al. 1997, Hobbs et al. 2002, 2012, Entwisle et al. 2013). The GIS is designed so that the data can be located to a point in space. Fortunately, in the case of the data in Glasgow, the City Council gained the permission of nearly all the data providers, public and private, to allow its use both in the Glasgow Geotechnical GIS and by the third parties who are part of the Accessing Subsurface Knowledge Network (ASK Network) (for their website, see reference list below), which is an initiative of the Council and the BGS to make subsurface information more easily available. As well as being a source of previously collected data, the Glasgow Geotechnical GIS also provides a method of displaying data and information for central Glasgow for desk study purposes. It is currently being tested by Glasgow City Council and will be further tested by the ASK network. Its potential uses, additions and changes will then be assessed after comments have been returned.

\section{DATA PRESENTATION}

The data in the Glasgow Geotechnical GIS are presented in four main ways:

- geographical distribution of borehole data; 
- plotted summary data;

- cross-sections of interpreted information;

- user-created plots.

The geotechnical data presented are restricted to the more common tests although other data could be included.

\section{Geographical distribution of borehole data}

As a part of any analysis of the data it is important to know the geographical location of the data used. A shape file is included in the GIS that provides the position and final depth of all boreholes and pits for which data have been included in the database. The distribution of boreholes and pits gives the user an understanding of the spatial density of the data and where there are gaps. The depth of drilling, when used with data from the 3D digital geological model, will indicate which of the geological units are likely to have been intercepted by a borehole.

\section{Plotted summary data}

Summary data plots are used to provide a rapid and easy way of assessing the distribution of parameter values for a given lithostratigraphical unit, or to determine the possible lithological controls, or to compare different units. Properties, such as plasticity, that require a specific style of plot are also provided. Statistical analysis to show the distribution of the data for each geotechnical property and for each lithostratigraphical unit is presented as extended box and whisker plots (if sufficient data exist). The philosophy of using non-parametric statistics to summarise geotechnical data was outlined by Hallam (1990) and Culshaw (2005) who also discussed some of the advantages of using non-parametric rather than parametric statistics. The percentiles displayed in the extended box and whisker plots depend on the number of values in the population to ensure that the outermost box, at each end, contains a minimum of three values and that at least two further values fall beyond the last 'box.' Fig. 5 shows the percentiles presented in relation to the number of data values. Percentiles are used for a range of parameters for each lithostratigraphical unit or for a number of lithostratigraphical units so they can be compared. Fig.6 is a box and whisker plot of undrained shear strength for the superficial deposits. It shows the different number of test results available for each lithostratigraphical unit, ranging from four for the Passage Formation (PGP) to 211 for the Upper Limestone Formation (ULGS). Fig. 7 shows the variation in strength of the different 
bedrock lithologies. Percentiles can also be used to display data that could be displayed as cross-plots where there are a large number of data and showing each individual sample in a cross-plot might be confusing. For example, the NGPD contains test data for 616 particle size tests for the Paisley Clay Member. It is impractical to show all the data on a summary graph; instead, the data are summarised using percentiles as shown in Fig. 8, while a plot for the Ross Sand Member, which contains 16 samples, shows the particle size distribution of each test (Fig. 9). Consolidation data could also be displayed in this way. However, there were insufficient consolidation data for any one lithostratigraphic unit in the database to justify the use of percentiles.

\section{Plotting descriptive data}

\section{Summarising descriptive information}

Much of the data contained in site investigation reports is of geotechnical parameters, mainly obtained from in situ or laboratory tests over a depth range. Descriptive information is available for a great deal more core than is covered by field and laboratory tests, potentially all material drilled. It also includes those materials that are difficult to sample or prepare for laboratory tests, for instance extremely weak to very weak mudstones. In these cases, the description may be the most useful or only information available. The importance of detailed descriptions is well understood in ground engineering and engineering geology. The codes of practice for site investigation (BSI 1981, 1999, 2007b, 2010) and the international standards (BSI 2002, 2003, 2004) provide methods for describing material from boreholes, pits and exposures. Within the GIS the described lithology, soil consistency or density and rock strength are presented for the various lithostratigraphical units. The percentages are calculated using Equation 1.

$$
L_{c a}(\%)=\frac{\sum L_{c d}}{\sum L_{c}} \times 100 \%
$$

Where $\mathrm{L}_{\mathrm{cd}}$ is the length of core of the lithostratigraphical unit $L$, with character $c$ (consistency, density, rock strength or lithology) and subset with character $d$, for instance: fine soils, very soft to very stiff (hard), or coarse soils very loose to very dense, or rocks, extremely weak to extremely strong ,or different lithologies. 
The total core length in metres for the main character, for example the lithostratigraphical unit or lithology, is given above each plot and this represents the sample size (see, for example, Fig. 10) .

Fig. 10 is an example of the variation of described primary and, in some cases, secondary lithology for each of the superficial deposits. The anthropogenic deposits contain an extra class where the lithology is not described, for instance where the material is described as 'fill' and presented as 'man-made'. The described strength of the bedrock units, using the nomenclature from BS5930:1999 (BSI 1999), shows that the intrusive rocks of the Western Midland Valley Westphalian to Early Permian Sills Formation are generally the strongest and the Passage Formation rocks the weakest (Fig. 11). Most of the data come for Scottish Middle and Lower Coal Measures Formation (LCMS and MCMS respectively) and the Upper Limestone Formation (ULGS). The central Glasgow area is mainly underlain by these units, therefore, they are likely to have been drilled and sampled but they also contain coal and have been mined.

\section{Information shown in the cross-sections}

Cross-sections provide information with depth along a line between two or more geographical points on the ground surface and are often used in linear infrastructure projects to present information and to inform the ground model. Cross-sections are drawn where there are enough suitable boreholes. In the GIS, the information may come from a single linear site investigation (for example, for a road) or from a number of investigations and for different types of project, including large building developments, roads and sewers. The length of cross-sections drawn (Fig. 12) varies from a little over $5 \mathrm{~km}$ to less than $1 \mathrm{~km}$. The northwest quarter of the central Glasgow area (Ordnance Survey Quarter Sheet NS56NE) did not have enough suitably spaced boreholes to draw a cross section. This was because the site investigations in this area were primarily for housing developments and so the pits and boreholes, generally less than $10 \mathrm{~m}$ deep, were clustered. The cross-sections were created using the 3D geological modelling software, GSI3D (Culshaw 2005, Kessler et al. 2009). Each cross-section also includes a location map of the area showing the line of the crosssection, the surface lithostratigraphy along the section and an explanatory key. The crosssections may include other information in 'boreholes,' such as lithology, described consistency, density or strength classification, standard penetration test classification (SPT) and rock quality designation (RQD) classes. The cross-section in Fig. 13 shows the lithostratigraphy and three borehole 'sticks' at each borehole site with colour-coded lithology in the left-hand 'stick,' described strength in the middle 'stick' and colour-coded Rock Quality 
Designation (RQD) in the right-hand 'stick.' This image can be enlarged when using the GIS. Faulting has not been included.

\section{Interpreted information and 'live' plots}

\section{Associated database}

The Glasgow Geotechnical GIS has a database of geotechnical data, a subset of the NGPD, from which the $x-y$ plots can be generated. The tables within the database contain project and borehole information such as grid coordinates, borehole starting height relative to OD and depth, description, lithostratigraphical unit associated with the description, a lithological code and the geotechnical parameters, which may be field tests, such as standard penetration test results, or laboratory test results. The tables included in the database are for the more commonly available data as listed below:

Field tests and measurements: Standard Penetration Test

Total core and solid core recovery

Rock Quality Designation

Fracture index

Laboratory tests:

Classification tests - water content, liquid limit, plastic limit, bulk density, dry density, particle density and percentage less than $0.425 \mathrm{~mm}$

Consolidation data - loading stress, voids ratio, coefficient of volume compressibility and coefficient of consolidation

Triaxial strength - undrained shear strength, effective stress parameters

Particle size classes - clay, silt, fines, sand, gravel

Point load test - point load index

Rock tests - water content, porosity, bulk density, dry density

Engineering chemistry - $\mathrm{pH}$ solid, $\mathrm{pH}$ water, acid soluble (total) sulfate, 2:1 aqueous soluble sulfate, water sulfate, acid soluble chloride, water chloride, carbonate content as $\mathrm{CO}_{2}$, organic content 
The depths are presented in three ways: as the mean depth below ground level, the mean depth relative to Ordnance Datum and the mean depth below the top of the lithostratigraphical unit.

\section{Making selections in the GIS}

The GIS provides an interface to display geology and images (see below) and returns a list depending on the search criteria and the display selected. The GIS was initially developed using Arc3.3 and then further developed in ArcMap 9.3. Unfortunately, each change in the version of the GIS requires some rewriting of the tool scripts and this is likely to be the case with subsequent versions of the ArcGIS. The additional functionality was generated using Visual Basic for Applications (VBA) and ArcObjects. The functions are all called from within the GIS by a series of buttons on the toolbar or by interrogating a particular geological layer in the GIS. In the latter case, the search performed by the GIS is automatically restricted so that any results are filtered by the selected geological layer.

\section{Display images}

Called from within the GIS, this function lists all the images that match a particular search criterion. The function will either search on lithostratigraphical unit ('select formation'), cross-section, or graph type (for example, a box and whisker plot). The formation selection uses the general vertical section (gvs), which is a list of the geological units used to create the 3D geological model in the order in which they occur (Kessler et al., 2009). This also includes codes for 'All soil' and 'All rock' for plots that compare the characteristics of anthropogenic and superficial or bedrock units. The selected images are then opened alongside the GIS, allowing the user to reference both the GIS and the images. The selection of Fig. 10 within the GIS is for selected formation 'All soil' and the selected plot 'Lithology all Soil'. A number of plots or cross-sections can be selected at a time. The image is presented in the default viewer.

\section{Displaying data as graphs (plots)}

This function allows the user to specify a data table from a database held outside the GIS. The data tables available in the central Glasgow Geotechnical GIS are listed above. 
Each of the parameters within a table can be plotted against any of the others or against any of the depth types available. These parameters are listed with the words to be used on the axes and title of the graph in an Arc table and are part of the GIS.

The selected numerical fields are extracted from the database and displayed as a scattergraph. The data displayed are filtered by lithostratigraphical unit (group, formation, member), and classification (lithology or topographical quarter sheet) as required. The lithological classification of the data points may be shown on the graph and on the map. Alternatively, the data search can be restricted to a quarter sheet. For example, the plot selection of the Middle Coal Measures Scotland Formation (MCMS) for unconfined compressive strength against depth below the top of the unit with differentiation for primary lithology type is shown in Fig. 14. The positions of the data points are shown alongside the scattergraph in the GIS map window (Fig. 15). The data can be further selected either by choosing points within a box from the graph or from the GIS map window. When selecting from the graph, the geographical position of the point or points are dynamically displayed in the GIS map. Points from an area have been selected in Fig. 15 and are shown in light blue. The resultant data are plotted in Fig. 16. The database table content for each point in these scattergrams can be read using the 'identify' tool.

\section{CONCLUSIONS}

The attributed 3D geological model and GIS that make up the Glasgow Geotechnical GIS provide a method of visualizing the geology and a wide range of other geodata as crosssections and graphs that characterize the geotechnical variability of the modelled units. The system can be used to communicate, to both specialists and non-specialists alike, a broad range of geological information from site investigations. The integration of information from the 3D geological model with the GIS provides a powerful desk study tool to aid both landuse planning at the city scale and the planning of specific ground investigations and, so, can be an important aid in achieving sustainable urban development. The extent of coverage of the data added to the database and presented in the GIS depends on: the spatial distribution of site investigations, the availability of the data from them, the ease with which the data can be added and, not least, the quality of the site investigations themselves.

The availability of the data and the GIS to external users depends on the confidentiality of the data and permission being given by the client to allow its use. Where permission is not given, 
the data cannot be provided to third parties. This will greatly restrict the use of data from the National Geotechnical Properties Database and the Glasgow Geotechnical GIS particularly for research, rather than as a long-term national resource. The ASK network can be seen as a model for providing geological and geotechnical data to a range of users for desk studies, particularly in urban areas where data are likely to be relatively plentiful.

Overall, the aim of the Glasgow Geotechnical GIS is to provide a desk study tool that contains information and data that can be readily accessible for a given site or area. The GIS was not designed for any specific project type (for example, a road scheme).

\section{ACKNOWLEDGEMENTS}

The paper is published with the permission of the Executive Director of the British Geological Survey (NERC).

\section{REFERENCES}

AGS. 2011. Electronic transfer of geotechnical and geoenvironmental data: AGS4 (Edition 4): Guidance document - specifying AGS format deliverables, first issue. Association of Geotechnical and Geoenvironmental Specialists, UK, 9p.

http://www.ags.org.uk/datatransferv4/GD01\%20-\%20Digital\%20Data\%20Specification\%20\%20v0.pdf

Aldiss, D. T., Black, M. G., Entwisle, D. C., Page, D. P., \& Terrington, R. L. 2012.

Benefits of a 3D geological model for major tunnelling works: an example from Farringdon, east-central London, UK. Quarterly Journal of Engineering Geology and Hydrogeology, 45, 405-414. http://nora.nerc.ac.uk/20346/

ARKLEy, S., Whitbread, K. \& Monaghan, A. 2013. Clyde superficial deposits and bedrock models released to the ASK Network 2013: a guide for users. British Geological Survey Open File Report OR/13/002. British Geological Survey, Keyworth, Nottingham. UK. http://nora.nerc.ac.uk/500548/

ASK NETWORK. http://www.bgs.ac.uk/asknetwork/home.html (accessed on 22 January 2014).

Browne, M. A. E., Forsyth, I. H. \& McMillan, A. A. 1986. Glasgow, a case study in urban geology. Journal of the Geological Society, 143, 509-520.

Browne, M. A. E. \& McMillan, A. A. 1989a. Geology for land use planning: Drift deposits of the Clyde valley. 3 volumes. British Geological Survey Technical Report, WA/89/78. British Geological Survey, Keyworth, Nottingham. 
Browne, M. A. E. \& McMillan, A. A. 1989b. Quaternary geology of the Clyde valley. British Geological Survey Technical Report SA/89/1. British Geological Survey, Keyworth, Nottingham. 63p.

BSI. 1975. BS 1377. British Standard methods of test for soil for civil engineering purposes. British Standards Institution, London.

BSI. 1981. BS5930: Code of practice for site investigation. British Standards Institution, London.

BSI. 1990. BS1377 British Standard methods of test for soil for civil engineering purposes, Parts 1 to 8. British Standards Institution, London.

BSI. 1999. BS5930: Code of practice for site investigation. British Standards Institution, London, UK. 199p.

BSI. 2002. BS EN ISO 14688-1 - Geotechnical investigation and testing - identification and classification of soil: Part 1: Identification and description. British Standards Institution, London. 12p.

BSI. 2003. BS EN ISO 14689-1 - Geotechnical investigation and testing - identification and classification of rock: Part 1: Identification and description. British Standards Institution, London. 16p.

BSI. 2004. BS EN ISO 14688-2 - Geotechnical investigation and testing - identification and classification of soil: Part 2: Principals for a classification. British Standards Institution, London. 12p.

BSI. 2007a. BS EN 1977: Eurocode 7 - Geotechnical design: Part 2: Ground investigation and testing. British Standards Institution, London. 196p.

BSI. 2007b. BS5930:1999+A1:2007. Code of practice for site investigations: amendment 1. British Standards Institution, London.192p.

BSI. 2010. BS5930: 1999+A2:2010. Code of practice for site investigations: amendment 2. British Standards Institution, London.192p.

Campbell, S. D. G., Merritt, J. E., Dochartaigh, B. E. O., Mansour, M. M., Hughes, A. G., Fordyce, F. M., EnTwisle, D. C., Monaghan, A. A. \& Loughlin, S. C. 2010. 3D geological models and their hydrogeological applications: supporting urban development: a 
case study in Glasgow-Clyde, UK. Zeitschrift der Deutschen Gesellschaft für Geowissenschaften, 161, 2, 251-262. http://nora.nerc.ac.uk/10391/

Connolly, T. \& BegG, C. 2005. Database systems: A practical approach to design, implementation and management. Addison Wesley, Boston, USA.

CulshaW, M. G. 2005. From concept towards reality: developing the attributed 3D geological model of the shallow subsurface. Quarterly Journal of Engineering Geology and Hydrogeology, 38, 231-284.

Entwisle, D. C., Wildman, G., Campbell, S. D. G., Merritt, J. E., SelF, S. J., Monaghan, A. A. \& ReEVeS, H. J. 2008. 3D geological modelling and geotechnical GIS for planning and development: an example from Glasgow, UK. In: "Cities and their underground environment," Proceedings of the 2nd European Regional Conference of the International Association of Engineering Geology and the Environment (EuroEnGeo 2008), Madrid, Spain. Asociación Española de Geologia Aplicada a la Ingeniería, Madrid. CD-ROM paper No. 046. http://nora.nerc.ac.uk/4991/

Entwisle, D. C., Hobbs, P. R. N., Northmore, K. J. Skipper, J., Raines, M. R., Self, S. J., ELlisON, R. A. \& JONES, L. D. 2013. Engineering geology of British rocks and soils: Lambeth Group. British Geological Survey Open Report OR/13/006. British Geological Survey, Keyworth, Nottingham. 318p. http://nora.nerc.ac.uk/503110/

Forster, A., Hobbs, P. R. N., Cripps, A. C., EnTwisle, D. C., FenwiCK, S. M. M., RAines, M. R., HALlam, J. R., Jones, L. D., SELF, S. J. \& MEAKIN, J. L. 1997. Engineering geology of British rocks and soils: Gault Clay. British Geological Survey Technical Report WN/94/031. British Geological Survey, Keyworth, Nottingham. 76p. http://nora.nerc.ac.uk/20421/

Forsyth, I. H., Hall, I. H. S. \& McMillan, A. A. 1996. The geology of the Airdrie district. Memoir of the British Geological Survey, 1:50 000 geological sheet 31W (Scotland). British Geological Survey, Keyworth, Nottingham.

Hall, I. H. S., Browne, M. A. E. \& Forsyth, I. H. 1998. The geology of the Glasgow district. Memoir of the British Geological Survey 1:50 000 Geological Sheet 30E (Scotland). British Geological Survey, Keyworth, Nottingham.

HALLAM, J. R. 1990. The statistical analysis and summarisation of geotechnical databases. British Geological Survey Technical Report WN/90/16. British Geological Survey, Keyworth, Nottingham. 35p. http://nora.nerc.ac.uk/20345/ 
Hobbs, P. R. N., EnTwisle, D. C., Northmore, K. J., Sumbler, M. G., Jones, L. D., Kemp, S. J., SELF, S. J., BARON, A. J. M. \& MEAKIN, J. L. 2002. Engineering Geology of British rocks and soils: mudstones of the Mercia Mudstone Group. British Geological Survey Research Report RR/01/002. British Geological Survey, Keyworth. Nottingham, 159p.

http://nora.nerc.ac.uk/17270/1/OR12032.pdf

Hobbs, P. R. N., Entwisle, D. C., Northmore, K. J., Sumbler, M. G., Jones, L. D., Kemp, S. J., Self, S. J., BARON, A. J. M. \& MEAKIN, J. L. 2012. Engineering Geology of British rocks and soils: Lias Group. British Geological Survey Technical Report OR/12/032. British Geological Survey, Keyworth, Nottingham., 323p. http://nora.nerc.ac.uk/17270/.

Kessler, H., Turner, A. K. CulshaW, M. G. \& Royse, K. R. 2008. Unlocking the potential of digital 3D geological subsurface models for geotechnical engineers. In: Proceedings of the 2nd European Regional Conference of the International Association for Engineering Geology and the Environment (EuroEnGeo 2008), Madrid, Spain. Asociación Española de Geologia Aplicada a la Ingeniería, Madrid. CD-ROM paper No. 029. http://nora.nerc.ac.uk/3817/ Kessler, H., MATHERS, S. J. \& SoBisch, H-G. 2009. The capture and dissemination of integrated 3D geospatial knowledge at the British Geological Survey using GSI3D software and methodology. Computers \& Geosciences, 35, 1311-1321.

http://dx.doi.org/10.1016/j.cageo.2008.04.005

Price, S. J., Banks, V. J., Burke, H., Royse, K. R., Terrington, R. \& ThOrPe, S. 2010. Interpretation, description and representation of anthropogenic deposits. In: Moore, H. \& Fox, H. (eds), “Restoration and recovery: regenerating land and communities,” Whittles Publishing, Caithness, Scotland. 159-168. http://nora.nerc.ac.uk/12914/

Self, S. J., ENTwiSle, D. C. \& Northmore, K. J. 2012. The structure and operation of the BGS National Geotechnical Properties Database Version 2. British Geological Survey Internal Report, IR/12/056. British Geological Survey, Keyworth, Nottingham, 61p. http://nora.nerc.ac.uk/20815/

Smith, A. \& Ellison, R. A. 1999. Applied geological maps for planning and development. A review of examples from England and Wales, 1983 to 1996. Quarterly Journal of Engineering Geology and Hydrogeology, 32, S1-S44. 


\section{Tables}

Table 1. Bedrock of the central Glasgow area (after Forsyth et al. 1996, Hall et al. 1998).

Table 2. Description, age and depositional environment of the superficial deposits (after Browne and MacMillan 1989b).

Table 3. Availability of different geotechnical data types in the GIS from site investigation reports prior to 1983, between 1983 and 2000 and post 2000.

Table 4. Major projects ( $>50$ boreholes and pits).

Table 5. Engineering geological classification and description of superficial and artificial deposits.

\section{Figures}

Fig. 1. 3D geological model classified for engineering geological characteristics of a part of central Glasgow (Quarter Sheet NS66SW).

Fig. 2. Location of the study area.

Fig. 3. The distribution of boreholes for site investigations in year ranges 1967 to 1983, 1983 to 2000 and after 2000 .

Fig. 4. Simplified structure of the National Geotechnical Properties Database (NGPD).

Fig. 5. Percentiles used depending upon the number of data values (samples).

Fig. 6. Extended box and whisker plot of uniaxial compressive strength for each lithostratigraphical unit; the lithostratigraphical unit codes are given at the top of the plot (for key see Table 1).

Fig. 7. Extended box and whisker plot of the uniaxial compressive strength of the bedrock in central Glasgow differentiated by lithology.

Fig. 8. The particle size distribution of the Paisley Clay Member expressed as percentiles.

Fig 9. Particle size distribution of each of the 16 samples of the Ross Sand and Gravel Member.

Fig. 10. The principal soil types for each of the superficial deposits (for superficial unit key see Table 2).

Fig. 11. The percentage of described strength classes for the bedrock units.

Fig. 12. Examples of the line of cross-sections. 
Fig. 13. Cross-section showing lithostratigraphy and lithology, strength description and rock quality designation classification in borehole 'sticks'.

Fig. 14. Uniaxial compressive strength plotted against distance from the top of the unit: Middle Coal Measures Scotland differentiated by main lithology as selected in Figure 14 (grey is sandstone, green is siltstone and blue is mudstone).

Fig. 15. The area selection (in light blue) for data points in the rock testing table selected as for Figure 14.

Fig. 16. The selected data from Figure 15. Brown points are sandstone and purple is siltstone. 
Table 1. Bedrock of the central Glasgow area (after Forsyth et al. 1996, Hall et al. 1998).

\begin{tabular}{|c|c|c|}
\hline $\begin{array}{l}\text { Geological } \\
\text { Formation }\end{array}$ & Description & $\begin{array}{l}\text { Depositional } \\
\text { environment }\end{array}$ \\
\hline $\begin{array}{l}\text { Western } \\
\text { Midland Valley } \\
\text { Westphalian to } \\
\text { Permian Sills } \\
\text { (WMVAS) }\end{array}$ & $\begin{array}{l}\text { Olivine dolerite sills intruded into all formations from } \\
\text { the Lower Limestone Formation to the Middle Coal } \\
\text { Measures. } \\
\text { Cathcart Sill - olivine microgabbro intruded primarily } \\
\text { onto the Lower Coal Formation. }\end{array}$ & \\
\hline $\begin{array}{l}\text { Upper Coal } \\
\text { Measures } \\
\text { Scotland } \\
\text { Formation } \\
\text { (UCMS) } \\
\end{array}$ & $\begin{array}{l}\text { Cycles of grey, commonly reddish brown or purple } \\
\text { sandstone, siltstone and mudstone. Some thin coal beds } \\
\text { near the top. }\end{array}$ & $\begin{array}{l}\text { Deltaic plain locally } \\
\text { with sand filled channels } \\
\text { and brief marine } \\
\text { incursions. Later } \\
\text { continental conditions } \\
\end{array}$ \\
\hline $\begin{array}{l}\text { Middle Coal } \\
\text { Measures } \\
\text { Scotland } \\
\text { Formation } \\
\text { (MCMS) }\end{array}$ & $\begin{array}{l}\text { Cycles of light grey to grey sandstone, grey to black } \\
\text { siltstone and mudstone with seat clay or seatearth and } \\
\text { coal at the top of each cycle. Coal seams are common } \\
\text { and are more than } 0.3 \mathrm{~m} \text { thick. }\end{array}$ & Coastal deltaic plain \\
\hline $\begin{array}{l}\text { Lower Coal } \\
\text { Measures } \\
\text { Scotland } \\
\text { Formation } \\
\text { (LCMS) } \\
\end{array}$ & $\begin{array}{l}\text { Cycles of light grey to grey sandstone, grey to black } \\
\text { siltstone and mudstone with seatclay or seatearth and } \\
\text { coal at the top of each cycle. Coal seams are common } \\
\text { and are more than } 0.3 \mathrm{~m} \text { thick. }\end{array}$ & $\begin{array}{l}\text { Fluvial Conditions } \\
\text { gradually becoming } \\
\text { broad, flat coastal deltaic } \\
\text { plain }\end{array}$ \\
\hline $\begin{array}{l}\text { Passage } \\
\text { Formation } \\
\text { (PGP) }\end{array}$ & $\begin{array}{l}\text { Sandstone, with thin usually mottled or multicoloured } \\
\text { red, purple, green and yellow mudstone and limestone } \\
\text { bed. Coal beds are rare }\end{array}$ & $\begin{array}{l}\text { Dominantly fluvial with } \\
\text { intermittent floodplain } \\
\text { deposits }\end{array}$ \\
\hline $\begin{array}{l}\text { Upper } \\
\text { Limestone } \\
\text { Formation } \\
\text { (ULGS) }\end{array}$ & $\begin{array}{l}\text { Upper part: Two major cycles of thin limestone bed } \\
\text { covered with thick mudstones, sandstone with } \\
\text { limestone at the top. } \\
\text { Lower part: Basal limestone, mudstone, sandstone and } \\
\text { limestone. }\end{array}$ & $\begin{array}{l}\text { Upper part: marine, } \\
\text { deltaic and alluvial } \\
\text { conditions. } \\
\text { Lower part marine with } \\
\text { periodical strong } \\
\text { currents bringing silt and } \\
\text { sand. }\end{array}$ \\
\hline $\begin{array}{l}\text { Limestone } \\
\text { Coal } \\
\text { Formation } \\
\text { (LSC) }\end{array}$ & $\begin{array}{l}\text { Upper part: upward sequence of coal, mudstone, } \\
\text { siltstone, sandstones, siltstone and seatearth with a few } \\
\text { thin limestone beds. } \\
\text { Lower part: dark grey mudstone, with siltstone, sand } \\
\text { stone, many ironstone beds with ironstones or coal neat } \\
\text { the top. }\end{array}$ & \\
\hline
\end{tabular}


Table 2. Description, age and depositional environment of the superficial deposits (after Browne and MacMillan 1989b).

\begin{tabular}{|c|c|c|c|c|}
\hline Formation & Geological unit & Description & Age & $\begin{array}{l}\text { Depositional } \\
\text { Environment }\end{array}$ \\
\hline & Peat & & Holocene & \\
\hline \multirow[t]{2}{*}{\begin{tabular}{|l|} 
Clyde Valley \\
Formation (CLVY)
\end{tabular}} & $\begin{array}{l}\text { Law Sand and } \\
\text { Gravel Member } \\
\text { (LAWSG) }\end{array}$ & $\begin{array}{l}\text { Grey, sand or silty sand with occasional } \\
\text { gravel, sometimes organic }\end{array}$ & Holocene & Recent fluvial \\
\hline & $\begin{array}{l}\text { Strathkelvin Clay } \\
\text { and Silt Member } \\
\text { (KELV) }\end{array}$ & $\begin{array}{l}\text { Clay or silty clay with many layers of silt } \\
\text { and locally sand with peat or organic } \\
\text { beds. }\end{array}$ & Holocene & $\begin{array}{l}\text { Flood plain or } \\
\text { lacustrine }\end{array}$ \\
\hline \multicolumn{2}{|c|}{ Gourock Formation (GUF) } & $\begin{array}{l}\text { Commonly, top metre or so of brown silty } \\
\text { clay with wisps of peat and some sand } \\
\text { beds. Below, light yellow brown and grey } \\
\text { sometime silty, fine to coarse sand or sand } \\
\text { and gravel. }\end{array}$ & Holocene & $\begin{array}{l}\text { Estuarine and } \\
\text { fluvial }\end{array}$ \\
\hline \multirow{3}{*}{$\begin{array}{l}\text { Clyde Clay } \\
\text { Formation } \\
\text { (CLYDE) }\end{array}$} & $\begin{array}{l}\text { Killearn Sand and } \\
\text { Gravel Member } \\
\text { (KARN) }\end{array}$ & $\begin{array}{l}\text { Primarily reddish Brown or orange fine } \\
\text { sand with silt or clay layers with thin beds } \\
\text { of fine gravel or sand and gravel }\end{array}$ & \begin{tabular}{|l|} 
Latest \\
Devensian to \\
Loch Lomond \\
Stadial
\end{tabular} & Deltaic \\
\hline & \begin{tabular}{|l} 
Paisley Clay \\
Member (PAIS)
\end{tabular} & $\begin{array}{l}\text { Thinly to thickly laminated, Brownish } \\
\text { grey, greyish brown and grey clay and } \\
\text { silt, with occasional gravel; sand units in } \\
\text { some areas, }\end{array}$ & $\begin{array}{l}\text { Early } \\
\text { Windermere } \\
\text { Interstadial }\end{array}$ & \begin{tabular}{|l|} 
Raised \\
glaciomarine
\end{tabular} \\
\hline & $\begin{array}{l}\text { Bridgeton Sand } \\
\text { Member (BRON) }\end{array}$ & $\begin{array}{l}\text { Fine to medium, occasionally coarse sand } \\
\text { and bouldery, cobbley, gravelly sand. }\end{array}$ & $\begin{array}{l}\text { Late Devensian } \\
\text { to early } \\
\text { Windermere } \\
\text { Interstadial }\end{array}$ & $\begin{array}{l}\text { Outwash deposits } \\
\text { from rapid } \\
\text { drainage of 'Lake } \\
\text { Clydesdale' in } \\
\text { submarine } \\
\text { environment }\end{array}$ \\
\hline \multirow[t]{3}{*}{$\begin{array}{l}\text { Broomhouse Sand } \\
\text { and Gravel } \\
\text { Formation (BHSE) }\end{array}$} & $\begin{array}{l}\text { Ross Sand } \\
\text { Member (RSSA) }\end{array}$ & $\begin{array}{l}\text { Medium to fine sand with laminae and } \\
\text { thin bands of silt, silty sand. }\end{array}$ & $\begin{array}{l}\text { Dilmington } \\
\text { Stadial }\end{array}$ & $\begin{array}{l}\text { Deltaic deposits } \\
\text { into ice-dammed } \\
\text { lake 'Lake } \\
\text { Clydesdale' } \\
\end{array}$ \\
\hline & & $\begin{array}{l}\text { Variable; gravel and sand with cobbles } \\
\text { and boulders; sand, and gravelly sandy } \\
\text { clay. }\end{array}$ & $\begin{array}{l}\text { Dilmington } \\
\text { Stadial }\end{array}$ & $\begin{array}{l}\text { Fluvial and deltaic } \\
\text { Esker ridges, } \\
\text { mounds, kames }\end{array}$ \\
\hline & \begin{tabular}{|l|} 
Bellshill Clay \\
Member (BILL)
\end{tabular} & $\begin{array}{l}\text { Laminated dark brownish grey to } \\
\text { brownish grey clay with bands of silt and } \\
\text { sometimes sand beds. May have gravelly } \\
\text { clay up to } 450 \mathrm{~mm} \text { thick. }\end{array}$ & $\begin{array}{l}\text { Dilmington } \\
\text { Stadial }\end{array}$ & Lacustrine \\
\hline \multicolumn{2}{|c|}{ Wilderness Till Formation (WITI) } & $\begin{array}{l}\text { Jointed, brownish grey, grey or dark grey } \\
\text { gravelly sandy clay with isolated boulders } \\
\text { and cobbles with minor pockets and beds } \\
\text { of medium sand and laminated clay up to } \\
10 \mathrm{~cm} \text { thick. Occasional thick laminated } \\
\text { clay } 10 \mathrm{~m} \text { thick to the east of the area. }\end{array}$ & $\begin{array}{l}\text { Dilmington } \\
\text { stadial }\end{array}$ & Mostly sub glacial \\
\hline \multicolumn{2}{|c|}{$\begin{array}{l}\text { Cadder Sand and Gravel Formation } \\
\text { (CADR) }\end{array}$} & $\begin{array}{l}\text { Thickly bedded, bouldery, cobbley, gravel } \\
\text { and sand or gravelly sand and silt. }\end{array}$ & l Devensian & \\
\hline \multicolumn{2}{|c|}{ Broomhill Clay Formation (BRLL) } & $\begin{array}{l}\text { Laminated and thinly bedded reddish } \\
\text { brown with grey of light yellowish brown } \\
\text { silt and sand with occasional fine to } \\
\text { medium gravel also beds of gravelly clay. }\end{array}$ & $\begin{array}{l}\text { Early } \\
\text { Dilmington } \\
\text { Stadial }\end{array}$ & Glaciolacustrine \\
\hline \multicolumn{2}{|c|}{ Baillieston Till Formation (BNTI) } & $\begin{array}{l}\text { Reddish brown or brownish grey or dark } \\
\text { grey, gravelly sandy clay with occasional } \\
\text { boulders and cobbles }\end{array}$ & \begin{tabular}{|l|} 
Pre Dilmington \\
Stadial \\
Devensian
\end{tabular} & Mostly sub glacial \\
\hline
\end{tabular}


Table 3. Availability of different geotechnical data types in the GIS from site investigation reports prior to 1983, between 1983 and 2000 and post 2000.

\begin{tabular}{|l|c|c|c|c|}
\hline Test type & \multirow{2}{*}{$\begin{array}{c}\text { Number of } \\
\text { tests }\end{array}$} & \multicolumn{2}{|l|}{ \% of each test type for the year intervals indicated } \\
\cline { 3 - 5 } & & Pre 1983 & 1983 to 2000 & After 2000 \\
\hline Water content and plasticity & 5846 & 21 & 39 & 40 \\
\hline Unconsolidated undrained triaxial tests & 1891 & 21 & 28 & 51 \\
\hline Soils triaxial effective stress tests & 145 & 8 & 33 & 59 \\
\hline Rock tests & 850 & 0.5 & 52 & 48 \\
\hline Standard Penetration Tests (SPT) & 1891 & 21 & 36 & 43 \\
\hline Rock quality designation (RQD) & 4481 & 22 & 62 & 16 \\
\hline
\end{tabular}


Table 4. Major projects (>50 boreholes and pits).

\begin{tabular}{|l|l|c|c|}
\hline Project type & Project name & Report date & $\begin{array}{l}\text { Number of } \\
\text { boreholes }\end{array}$ \\
\hline Sports village & Commonwealth Games Village Phase II & $2010 ?$ & 253 \\
\hline Sporting facilities & Commonwealth Games Areas 1, 2 and 3 & 2008 & 129 \\
\hline Urban regeneration & East End Regeneration & 2004 & 174 \\
\hline Motorway & M74 completion & 2003 & 722 \\
\hline Redevelopment & Pacific Quay, Riverside Business Park & 1997 & 70 \\
\hline Redevelopment & Camberslang Investment Park & 1996 & 95 \\
\hline Redevelopment & Glasgow Pacific Quay & 1996 & 101 \\
\hline Motorway & M74 Northern Extension & 1993 & 78 \\
\hline Motorway & M8 Widening Eastbound stage 1 and & 1992 & 99 \\
\hline Relief Road & Bestbound stage 3 & 1990 & 97 \\
\hline Redevelopment & Camberslang Investment Park & 1983 & 77 \\
\hline Motorway & M80 Steppes Bypass & 1983 & 137 \\
\hline Motorway & M74 Glasgow to Maryville & 1981 & 59 \\
\hline Motorway & Glasgow, Springburn Expressway & 1979 & 148 \\
\hline Development & Govan, Riverside & 1974,1975 & 71 \\
\hline Motorway & Renfrew Motorway stages 1 and 2 & 1970 & 110 \\
\hline
\end{tabular}


Table 5. Engineering geological classification and description of superficial and artificial deposits.

\begin{tabular}{|c|c|c|}
\hline $\begin{array}{l}\text { Engineering geological } \\
\text { classification }\end{array}$ & Engineering Geological Description & Lithostratigraphical units \\
\hline Organic deposits & Highly compressible organic deposit & Peat \\
\hline \multirow[t]{3}{*}{$\begin{array}{l}\text { Mixed fine and course } \\
\text { grained deposits }\end{array}$} & $\begin{array}{l}\text { Highly variable, very soft to very stiff, very } \\
\text { loose to very dense, clay, silt, sand, gravel, } \\
\text { cobble and or boulders of natural and man- } \\
\text { made materials. }\end{array}$ & Anthropogenic deposits \\
\hline & $\begin{array}{l}\text { Loose to medium dense SAND and GRAVEL } \\
\text { or soft to firm (stiff) CLAY or SILT }\end{array}$ & $\begin{array}{l}\text { Gourock Formation } \\
\text { Head }\end{array}$ \\
\hline & $\begin{array}{l}\text { Firm to very stiff gravelly sandy CLAY with } \\
\text { occasional cobbles and boulders or very } \\
\text { dense SAND and GRAVEL or firm to stiff } \\
\text { CLAY or SILT }\end{array}$ & $\begin{array}{l}\text { Wilderness Till Formation } \\
\text { Baillieston Till Formation }\end{array}$ \\
\hline \multirow[t]{2}{*}{ Fine deposits } & $\begin{array}{l}\text { (Very soft) soft to firm laminated sometimes } \\
\text { sandy SILT or CLAY with occasional gravel }\end{array}$ & $\begin{array}{l}\text { Lacustrine deposits } \\
\text { Strathkelvin Silt and Clay } \\
\text { Member } \\
\text { Linwood Clay Member } \\
\text { Paisley Clay Member }\end{array}$ \\
\hline & $\begin{array}{l}\text { Firm to stiff (very stiff) sometimes laminated } \\
\text { CLAY/SILT }\end{array}$ & $\begin{array}{l}\text { Bellshill Clay Member } \\
\text { Broomhill Clay Formation }\end{array}$ \\
\hline \multirow[t]{3}{*}{ Coarse deposits } & $\begin{array}{l}\text { Loose SAND, gravelly SAND, sandy } \\
\text { GRAVEL or GRAVEL }\end{array}$ & Law Sand and Gravel Member \\
\hline & $\begin{array}{l}\text { Loose to dense (silty) SAND or SAND and } \\
\text { GRAVEL }\end{array}$ & $\begin{array}{l}\text { Killearn Sand and Gravel } \\
\text { Member } \\
\text { Ross Sand Member } \\
\text { Bridgeton Sand Member }\end{array}$ \\
\hline & $\begin{array}{l}\text { Medium dense to very dense } \\
\text { SAND/GRAVEL occasional boulders }\end{array}$ & $\begin{array}{l}\text { Broomhouse Sand and Gravel } \\
\text { Formation } \\
\text { Broomhouse Sand and Gravel } \\
\text { Formation (sand facies) } \\
\text { Cadder Sand and Gravel } \\
\text { Formation } \\
\text { Sand and Gravel } \\
\text { (Undifferentiated) }\end{array}$ \\
\hline
\end{tabular}




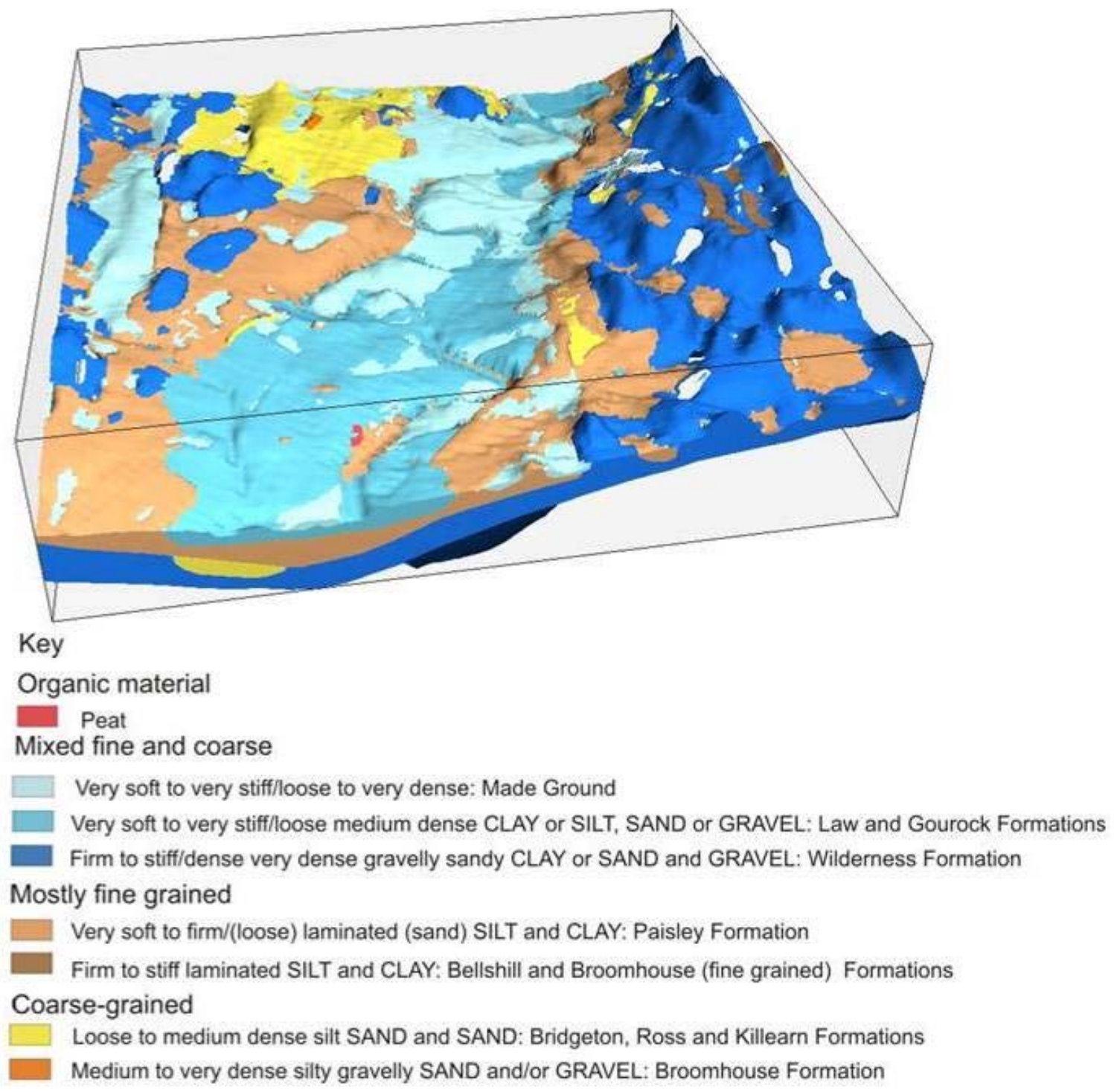

Figure 1. 3D geological model classified for engineering geological characteristics of a part of central Glasgow (Quarter Sheet NS66SW). 


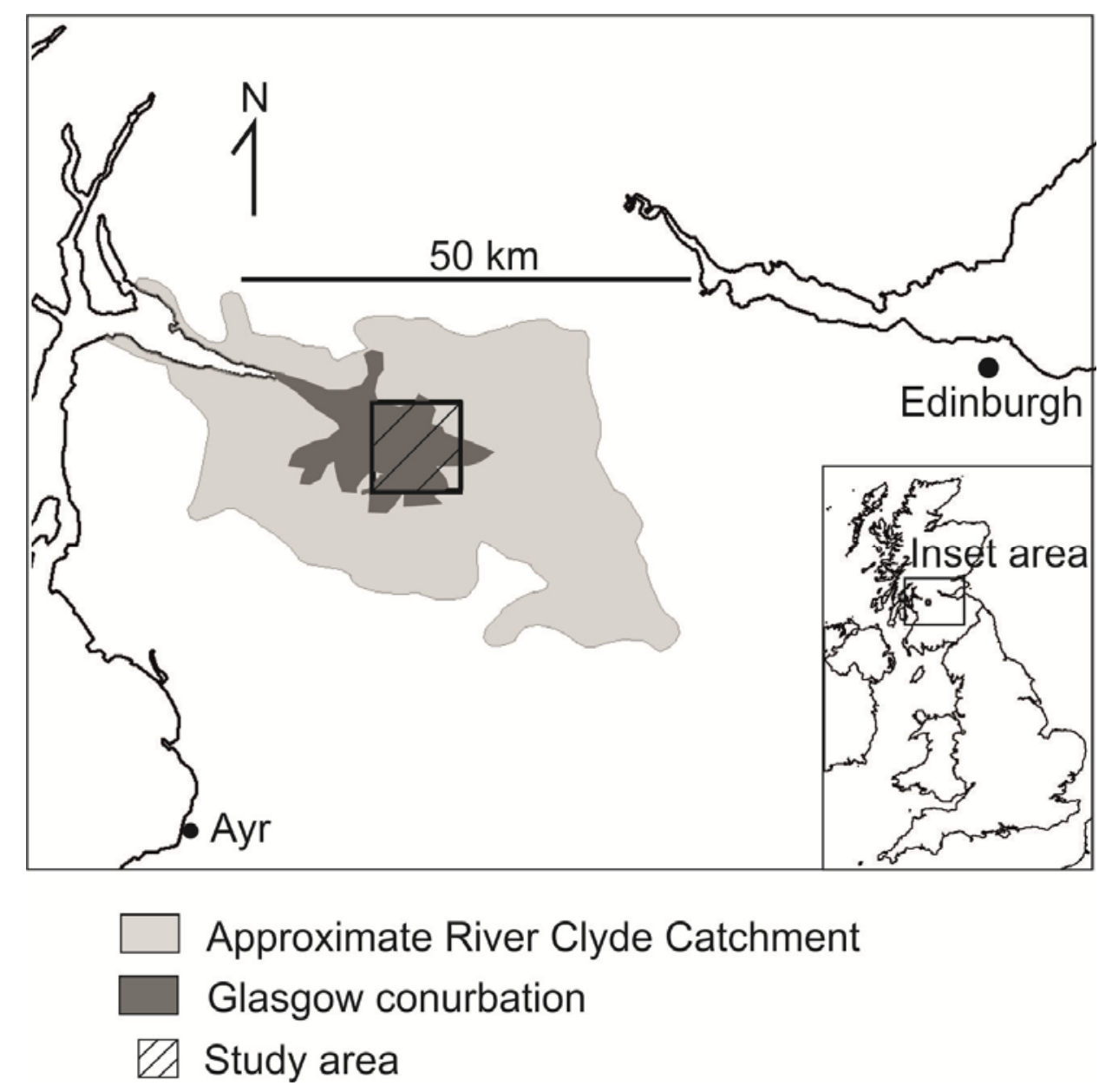

Figure 2. Location of the study area. 


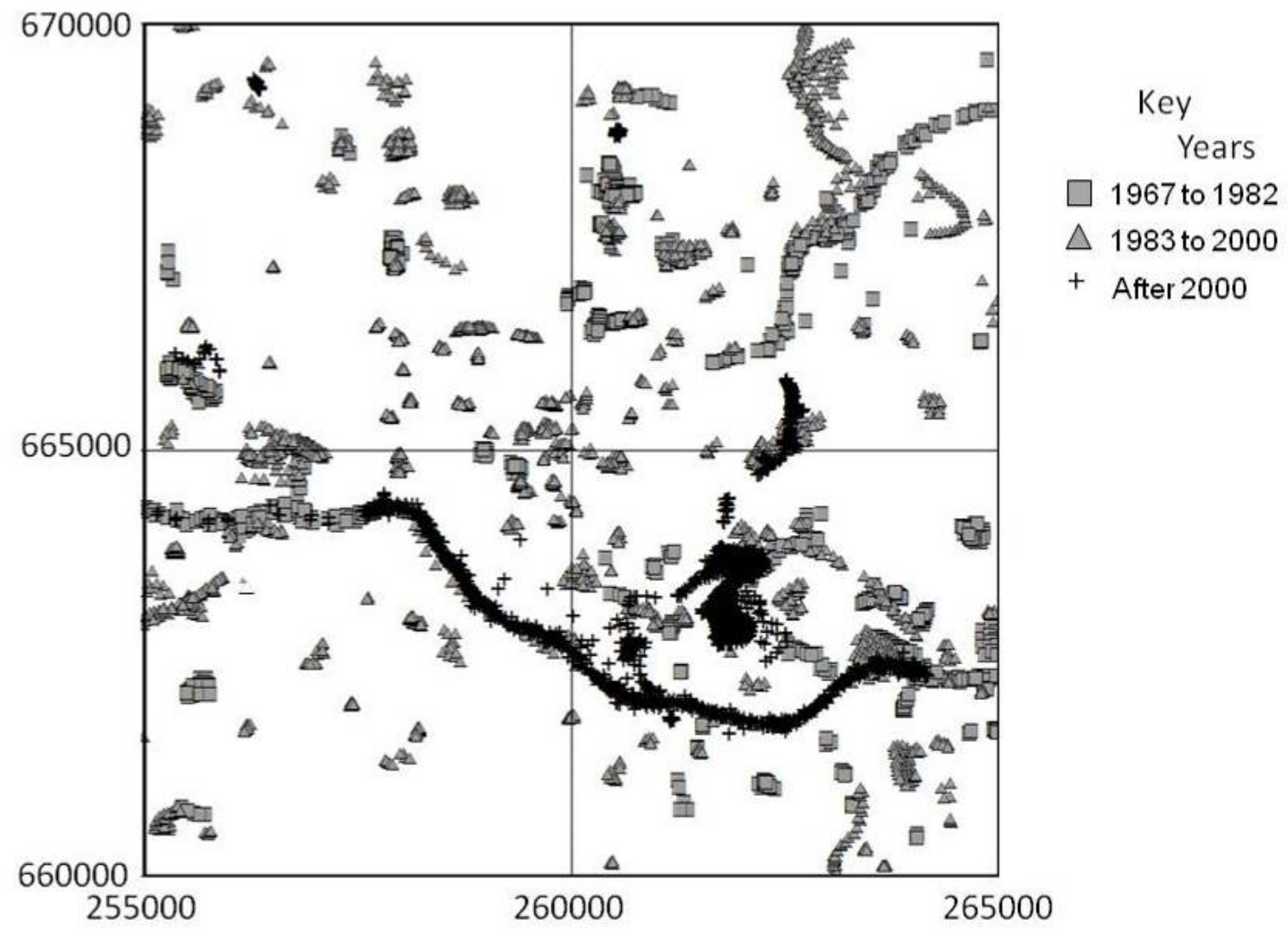

Figure 3. The distribution of boreholes in the study area shown in Fig. 1, for site investigations in year ranges 1967 to 1983, 1983 to 2000 and after 2000. 


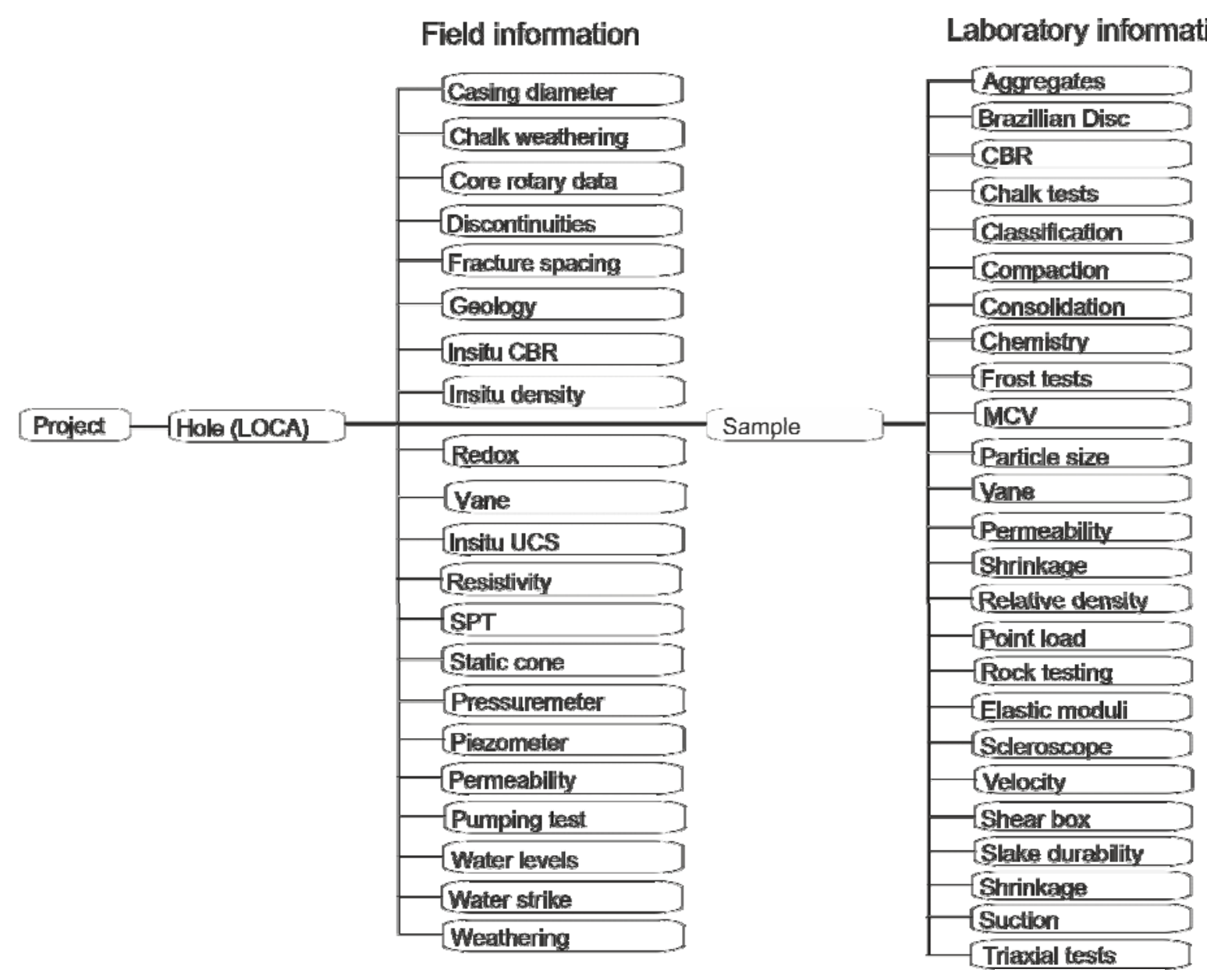

Figure 4. Simplified structure of the National Geotechnical Properties Database (NGPD). 


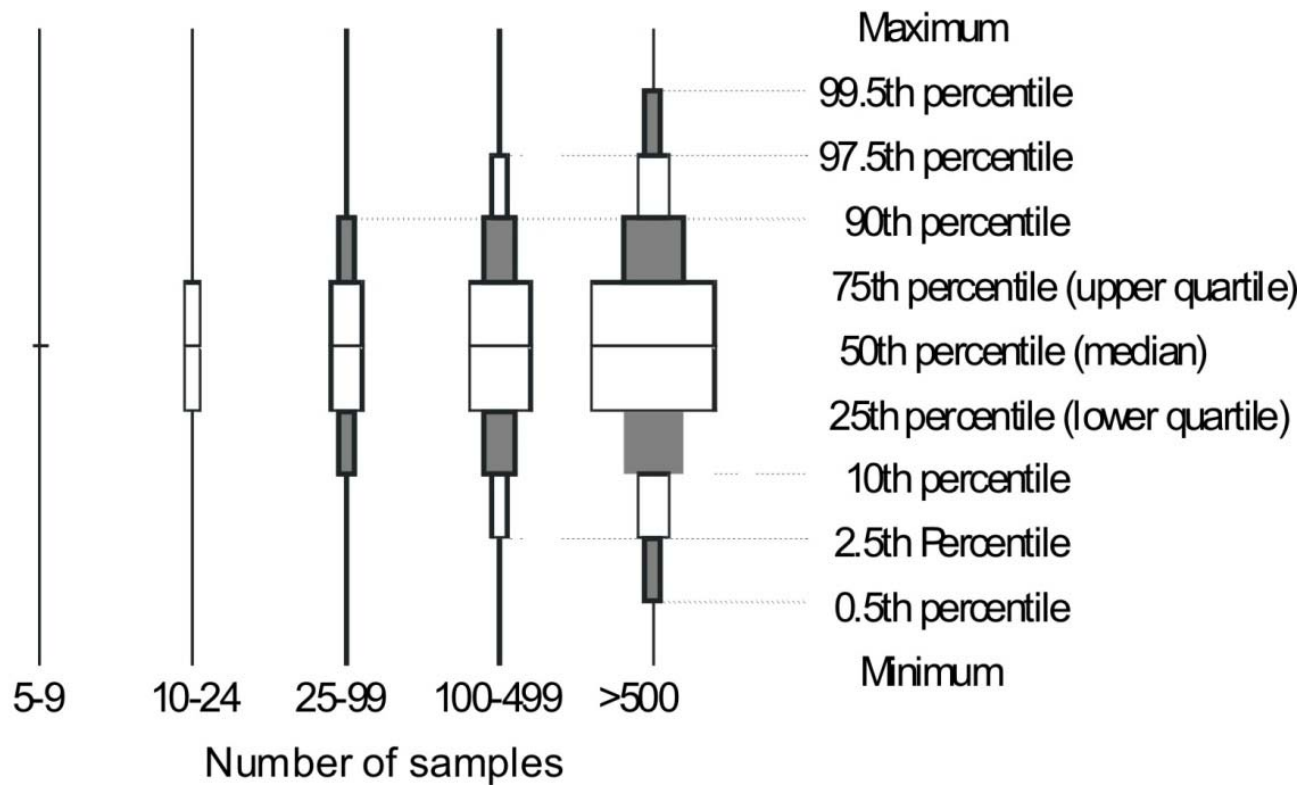

Figure 5. Percentiles used depending upon the number of data values (samples). 


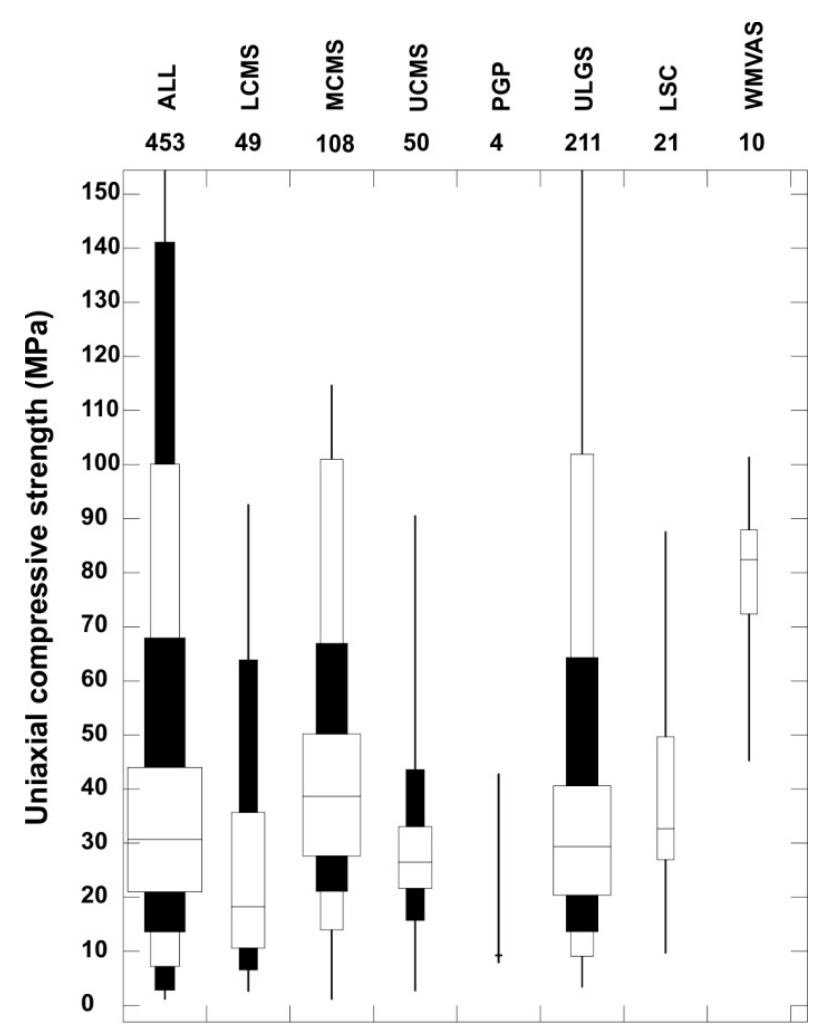

Figure 6. Extended box and whisker plot of uniaxial compressive strength for each lithostratigraphical unit; the lithostratigraphical unit codes are given at the top of the plot (for key see Table 1).

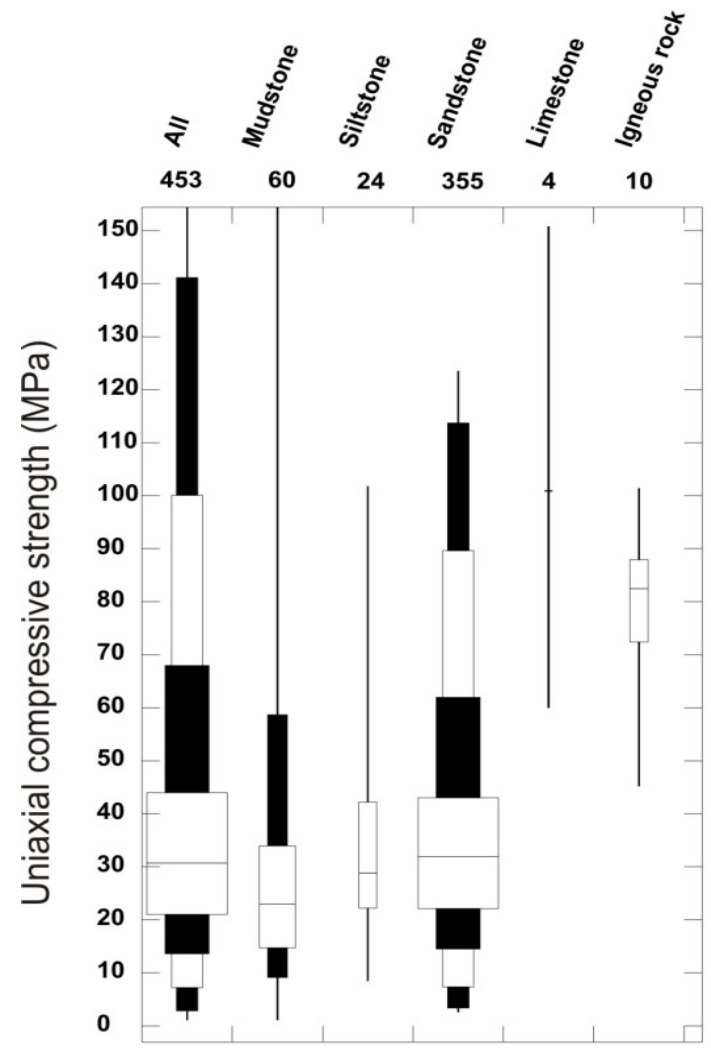

Figure 7. A box and whisker plot of the uniaxial compressive strength of the bedrock in central Glasgow differentiated by lithology. 


\section{Particle size distribution - Paisley Clay Member \\ 616 samples}

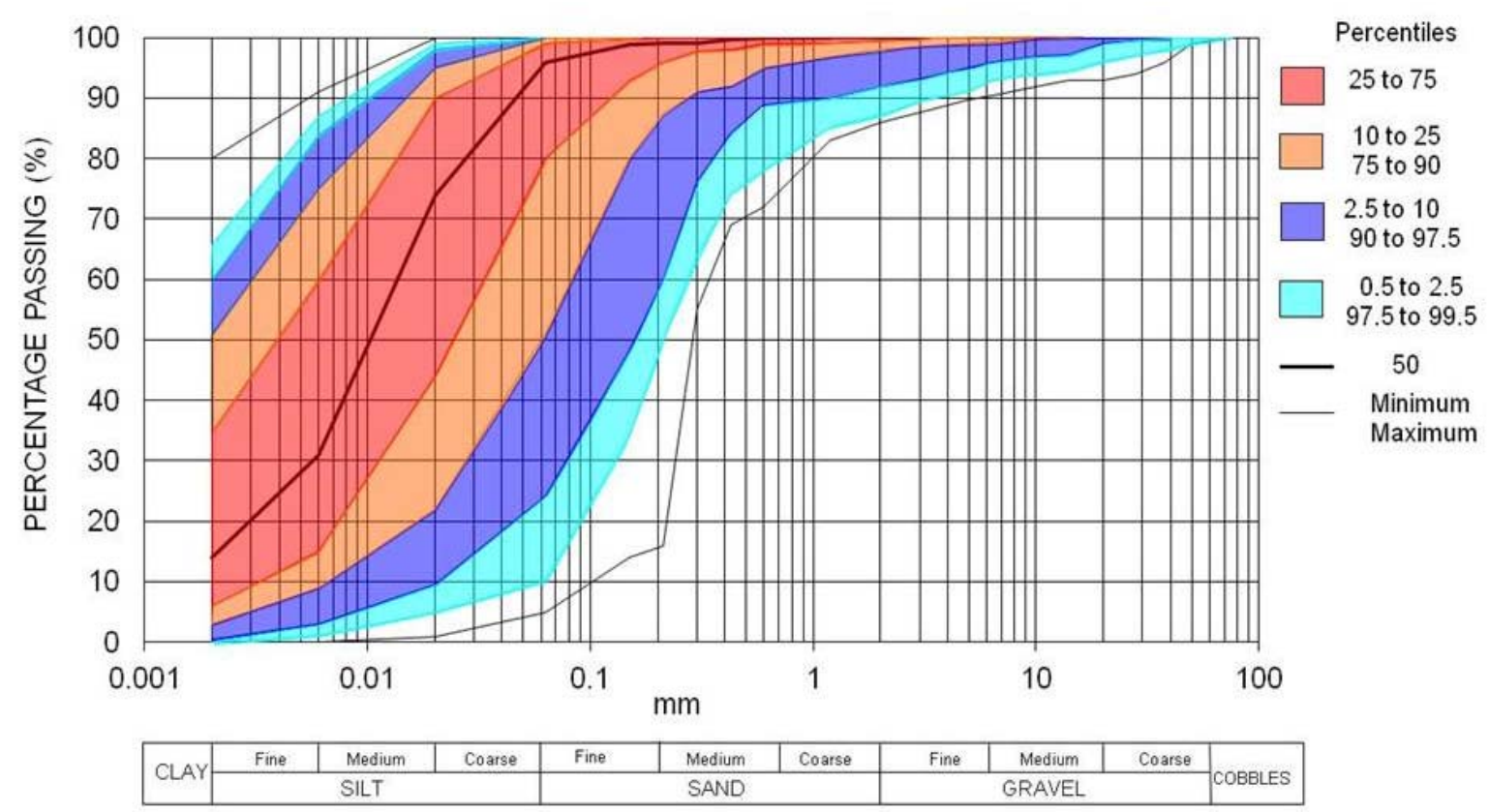

Figure 8. The particle size distribution of the Paisley Clay Member expressed as percentiles. 
Particle size distribution - Ross Sand and Gravel Member 16 samples

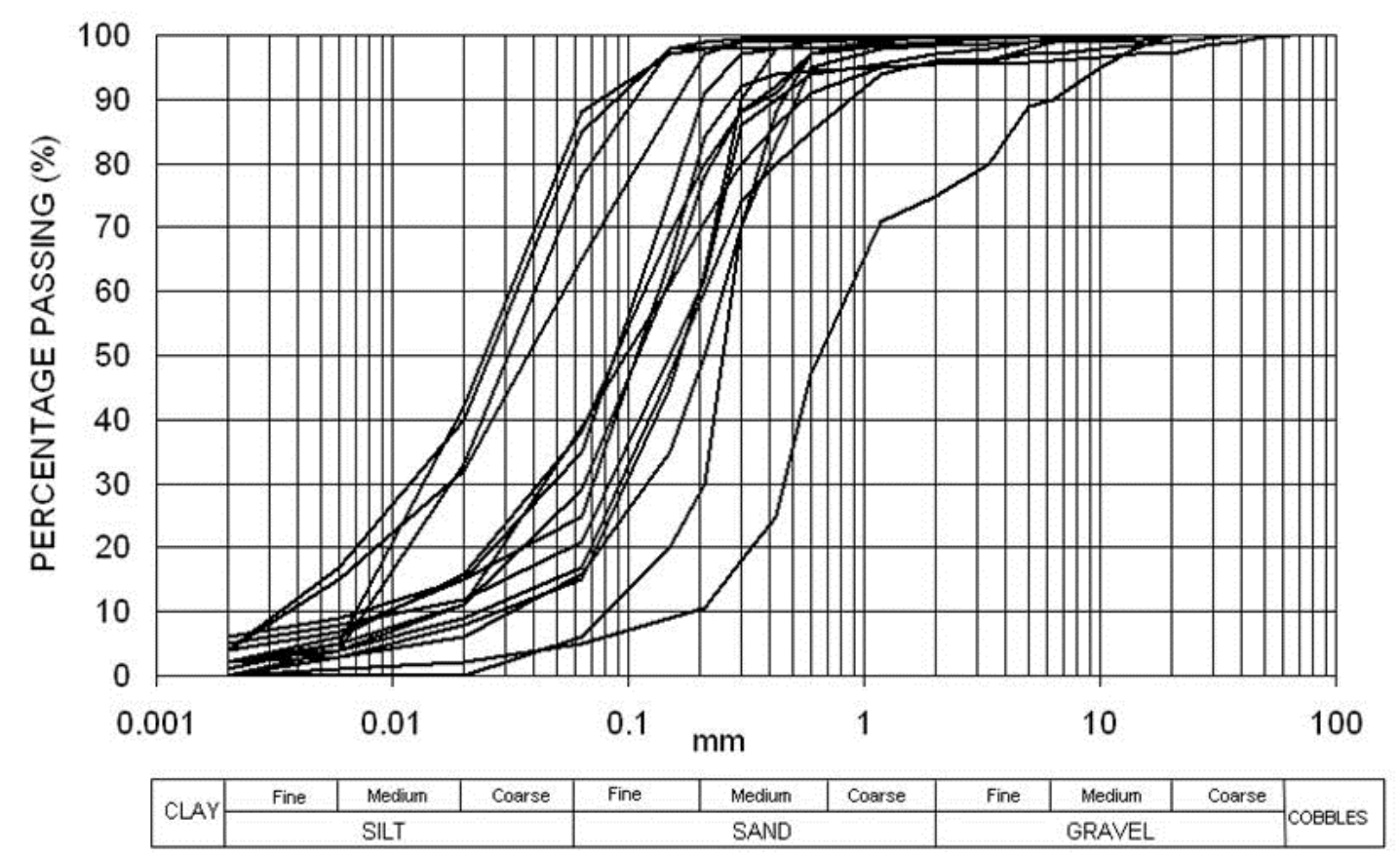

Figure 9. Particle size distribution of each of the 16 samples of the Ross Sand and Gravel Member. 
Principle soil type for each lithostatigraphical unit

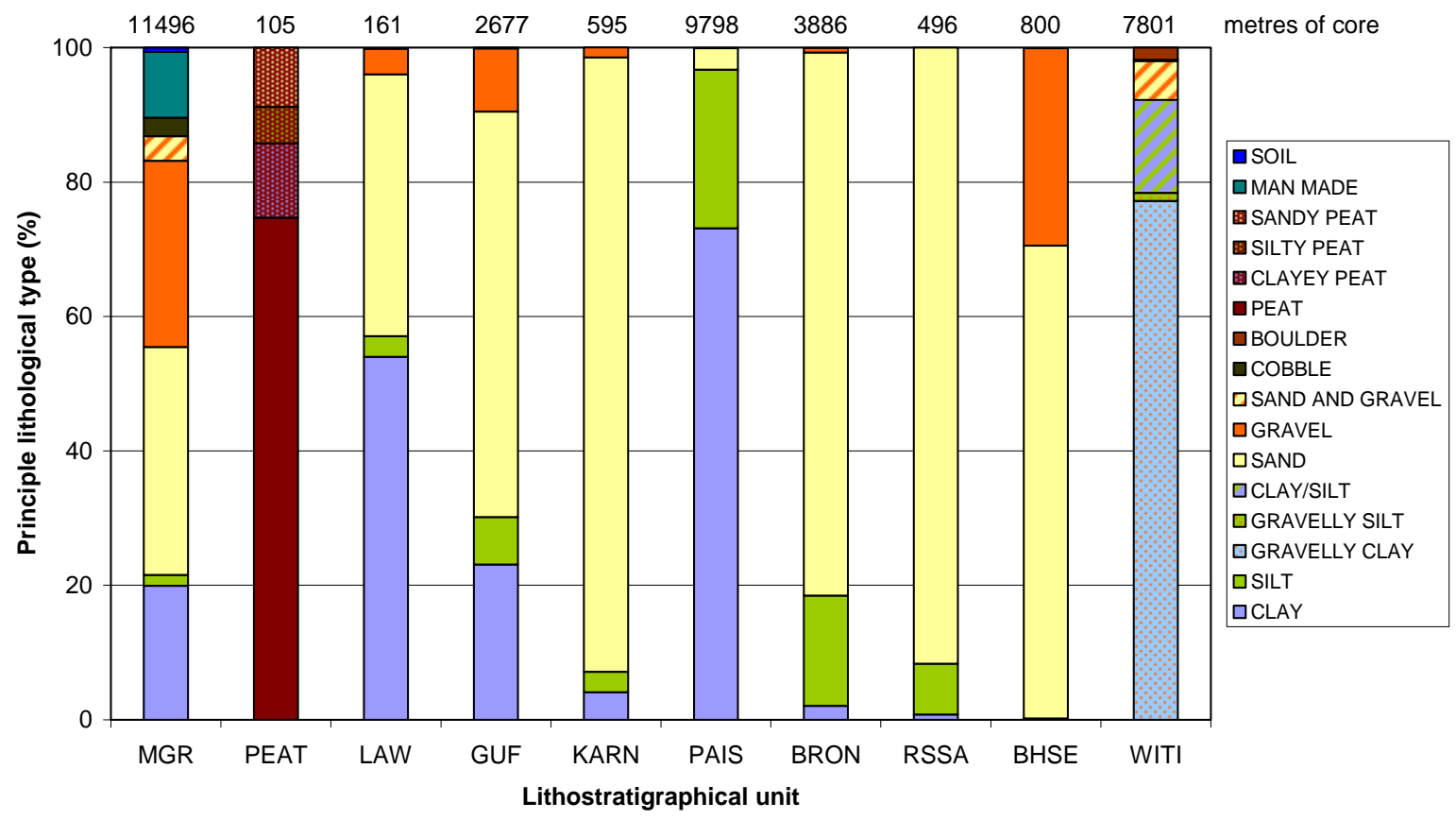

Figure 10. The principal soil types for each of the superficial deposits (for superficial unit key see Table 2).

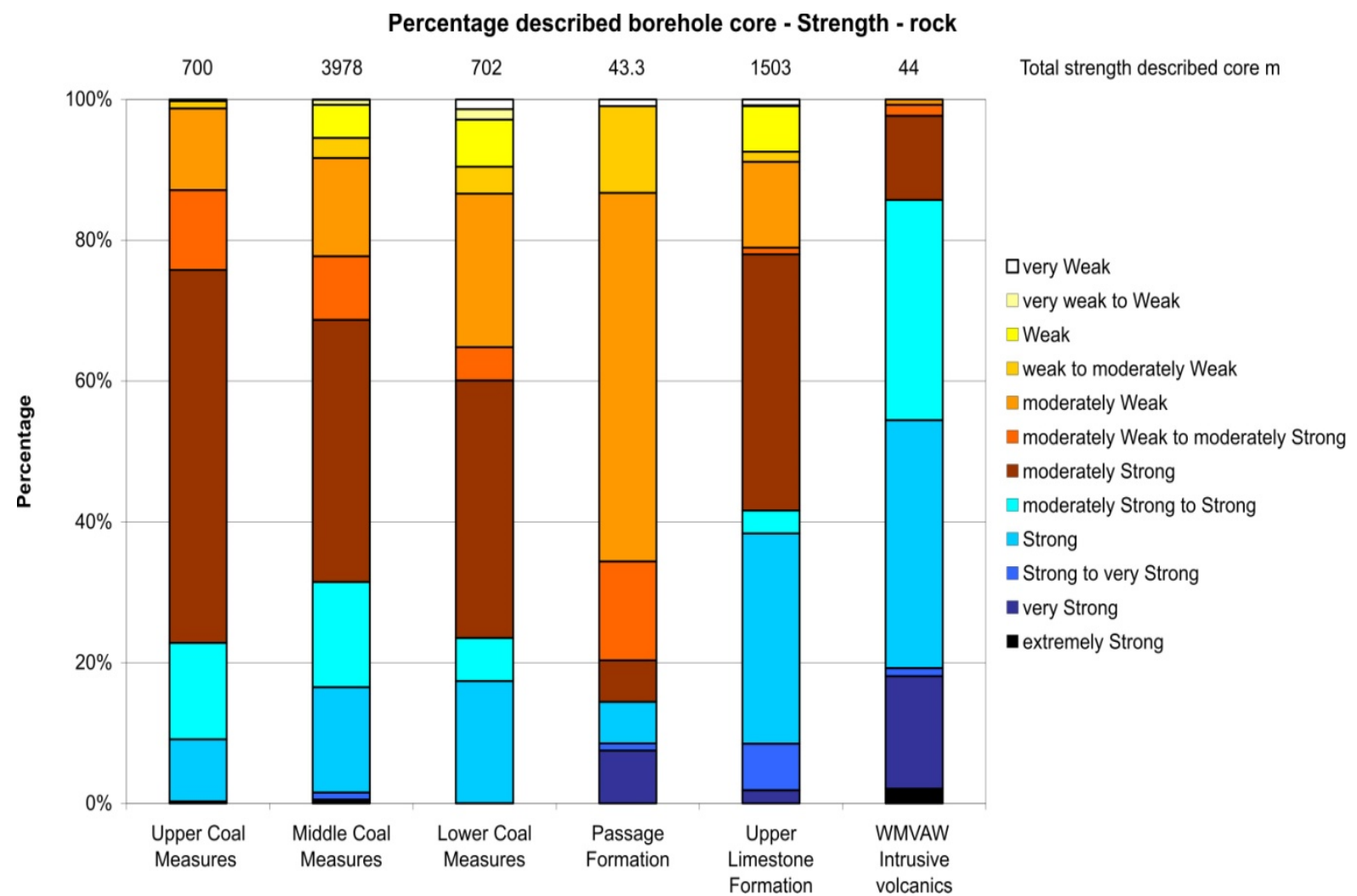

Figure 11. The percentage of described strength classes for the bedrock units. 


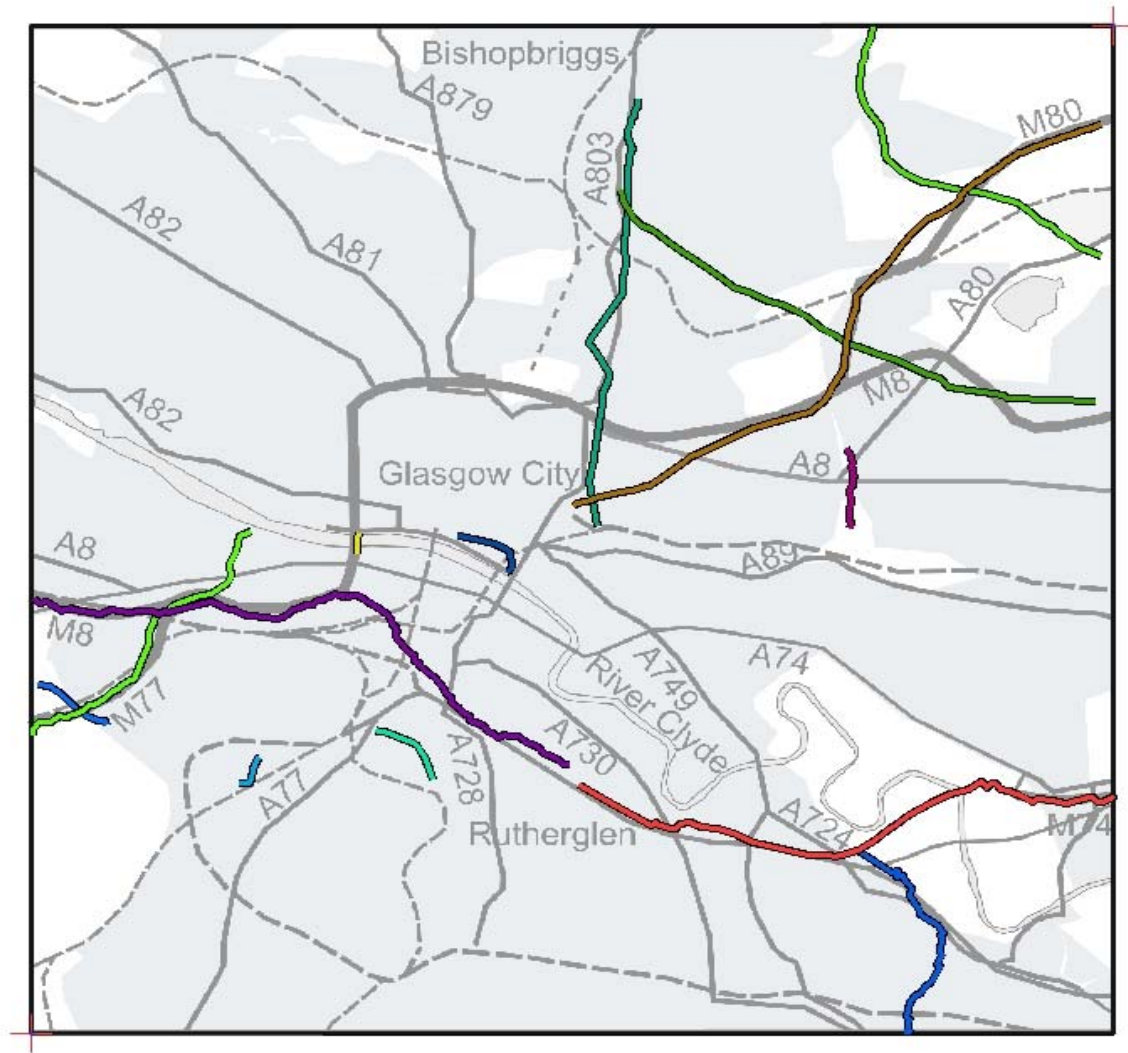

Figure 12. Examples of the line of cross-sections. 


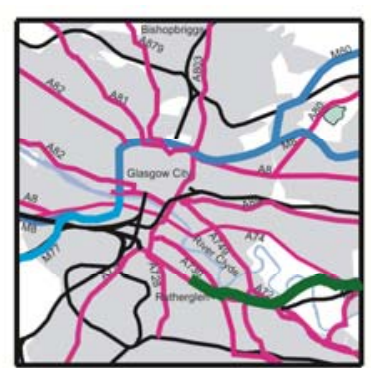

Section

A road

Motorway

Railway

Urban area

Rock Quality Designation

Very poor quality rock
Poor quality rock
Fair guality rock

Fair quality rock
Good quality rock
Excellent quality rock

Lithostratigraphy

Made Ground (Anthropogenic deposits)

Gourock Formation

Killearn Sand and Gravel Member

Paisley Clay Member

Ross Sand Member

Broomhouse Sand and Gravel Formation

Wilderness Till Formation

Scottish Middle Coal Measures Formation

Scottish Lower Coal Measures Formation

Lithology

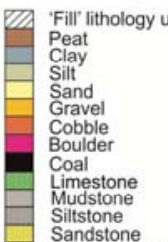

Fill' lithology un
Peat
Clay
Silt
Sand
Gravel
Cobble
Boulder
Coal
Limestone
Mudstone
Siltstone
Sandstone

silty Sandstone
Described strength/density

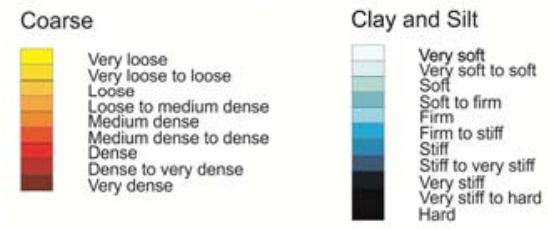

Rock strength

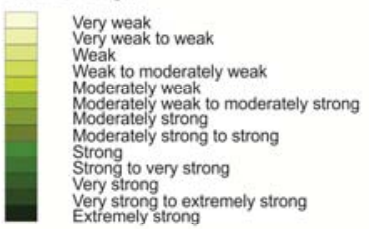

East

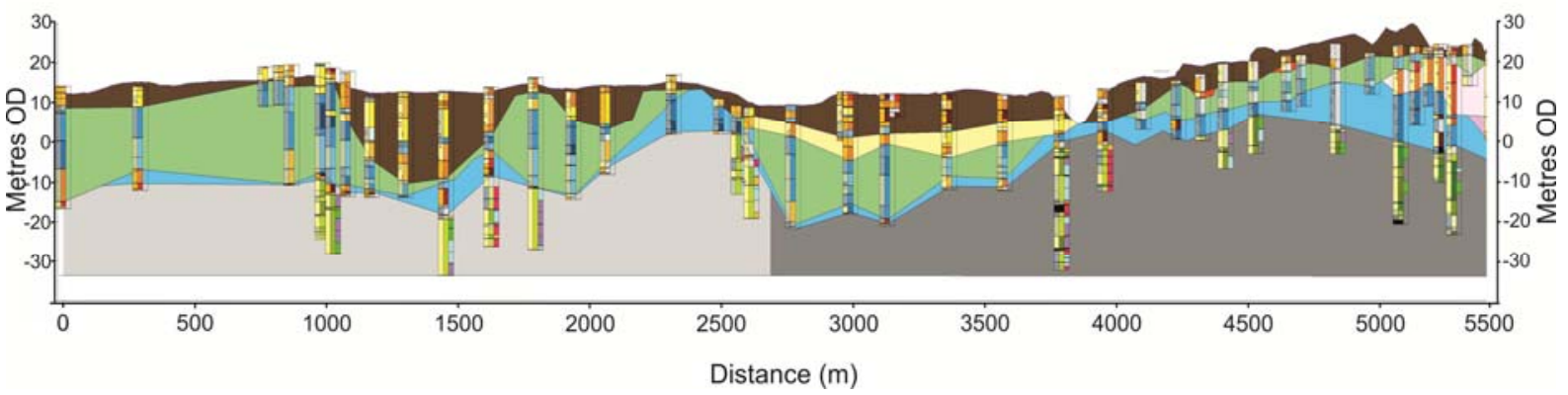

Figure 13. Cross-section showing lithostratigraphy and lithology, strength description and rock quality designation classification in borehole 'sticks'. 


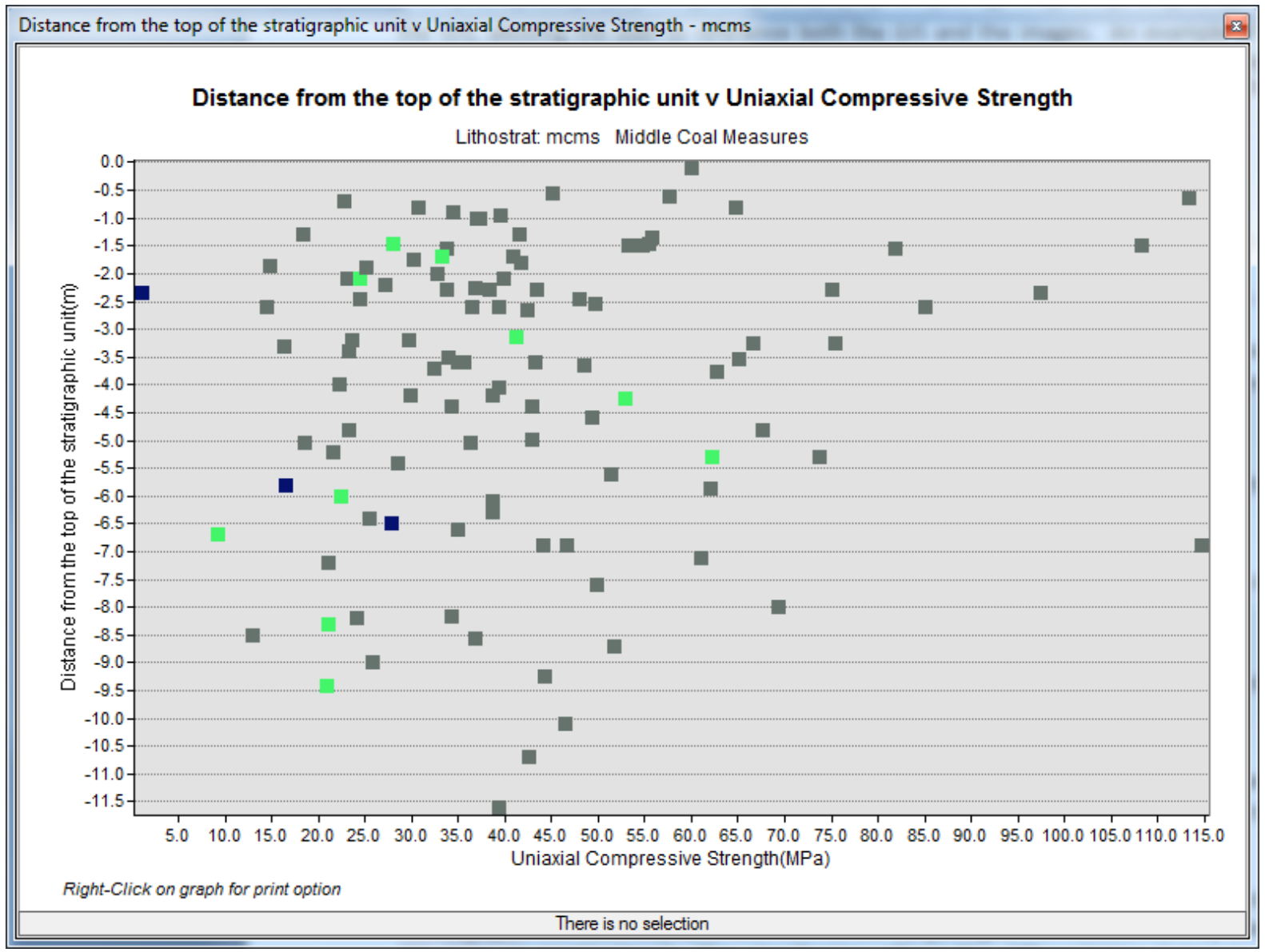

Figure 14. Uniaxial compressive strength plotted against distance from the top of the unit: Middle Coal Measures Scotland differentiated by main lithology (grey is sandstone, green is siltstone and blue is mudstone). 


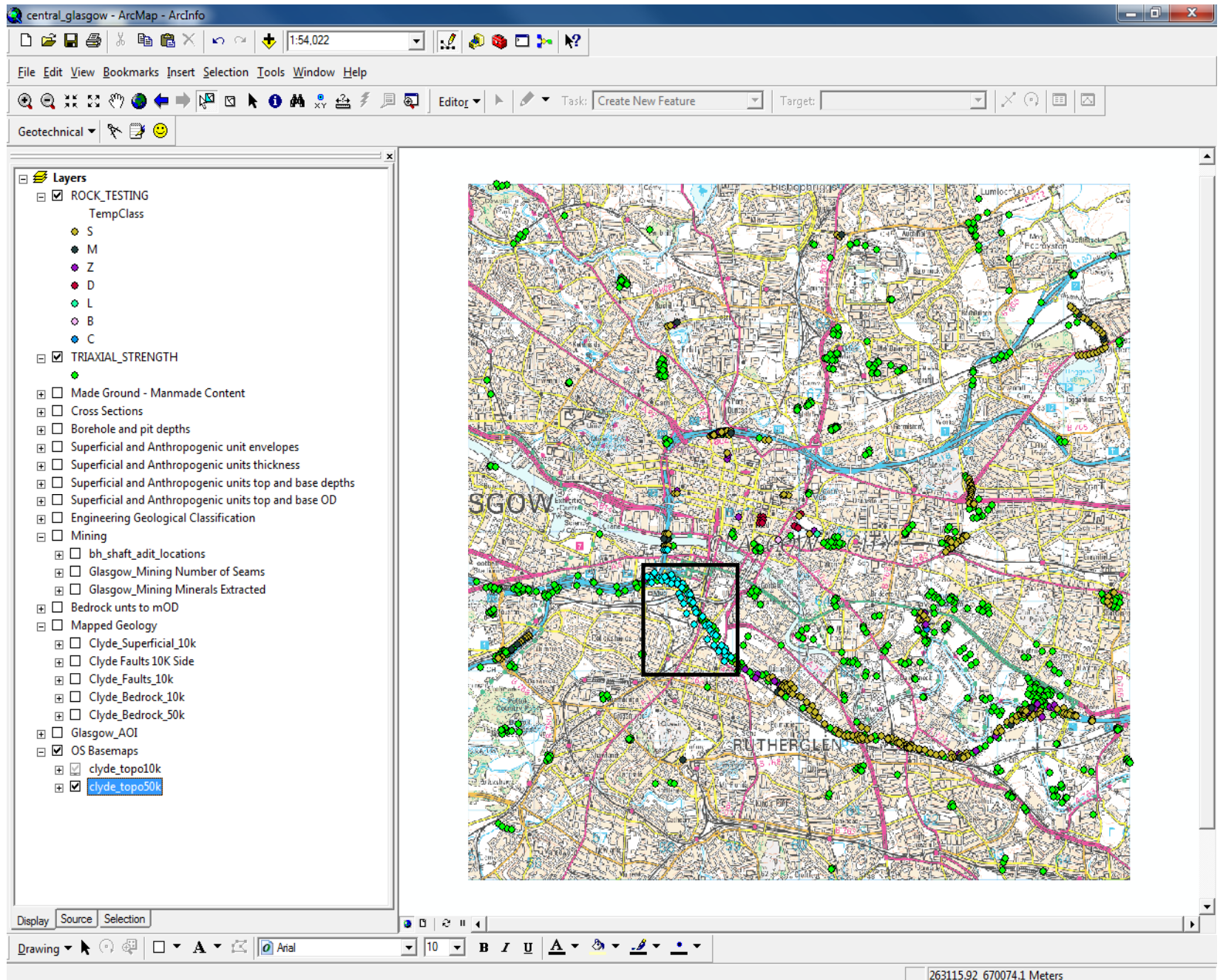

Figure 15. The area selection (outlined square and data points in light blue) for data points in the rock testing table selected as for Figure 14. 
Distance from the top of the stratigraphic unit $v$ Uniaxial Compressive Strength

Lithostrat: mcms Middle Coal Measures

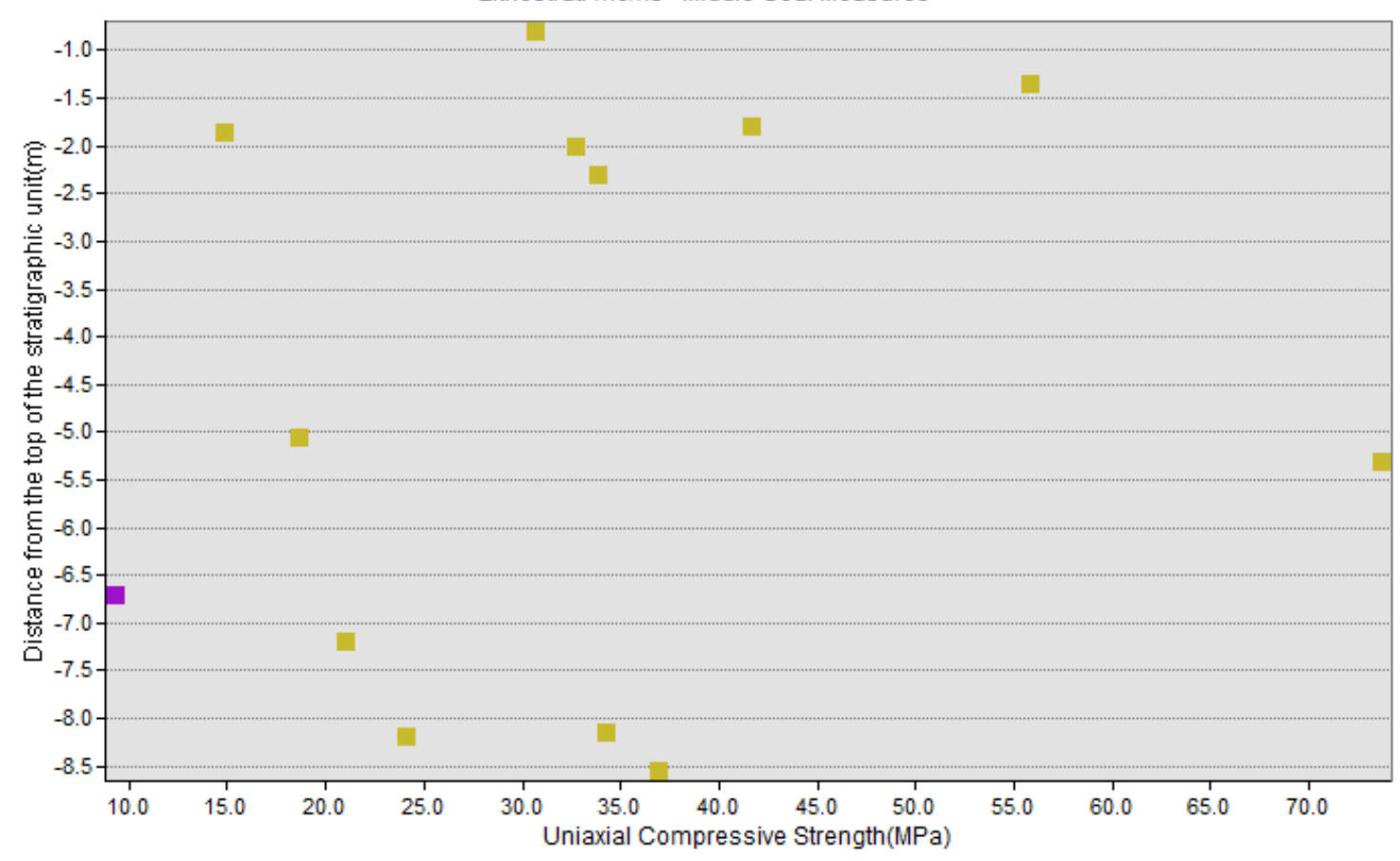

Right-Click on graph for print option

There is no selection

Figure 16. The selected data from Figure 15. Brown points are sandstone and purple is siltstone. 